\title{
Programas ideológicos a través de la imagem: algunos ejemplos de la Edad Media
}

\section{Marta Serrano Coll}

\section{OpenEdition}

\section{Journals}

\section{Edición electrónica}

URL: http://journals.openedition.org/medievalista/507

DOI: $10.4000 /$ medievalista.507

ISSN: 1646-740X

\section{Editor}

Instituto de Estudos Medievais - FCSH-UNL

\section{Referencia electrónica}

Marta Serrano Coll, « Programas ideológicos a través de la imagem: algunos ejemplos de la Edad Media ». Medievalista [En línea], 9 | 2011, Puesto en línea el 02 enero 2011, consultado el 30 abril 2019. URL : http://journals.openedition.org/medievalista/507 ; DOI : 10.4000/medievalista.507

\section{(C) IEM}


Titulo: Programas Ideológicos a través de la Imagem: algunos ejemplos de la Edad Media

Autor(es): Marta Serrano Coll

Enquadramento Institucional: Universitat Rovira i Virgili (Tarragona)

Contacto: mserrano@tinet.org

Fonte: Medievalista [Em linha]. №9, (Dezembro 2010). Direc. José Mattoso. Lisboa: IEM.

Disponível em: http://www2.fcsh.unl.pt/iem/medievalista/

ISSN: 1646-740X

\section{Resumo}

Sob a iconografia de Jaime Conquistador desenvolvem-se, de forma mais ou menos aberta, programas ideológicos realizados por organismos oficiais ou pela própria monarquia. Estes programas denotam um claro favorecimento da sua figura que, pouco a pouco, e depois da sua chorada morte, foi envolta numa áurea legendária ainda que, é certo, não tivesse tido o apoio da instituição eclesiástica. Acérrimo foralista, épico cruzado contra os infiéis sarracenos, protótipo de herói, a raiz duma gloriosa dinastia de Maiorca e Valença... É apenas uma pequena amostra dos diversos significados que as imagens compiladas sugerem, oferecendo uma visão extraordinária, ainda que nem sempre ajustada à realidade, do rei Jaime.

Palavras-chave: Jaime Conquistador, São Jorge, Iconografia, Instituição monarquica, liturgia regia. 


\title{
Abstract
}

The iconography of Jacques the Conqueror is the result of ideological programs originated by official institutions or by the monarchy itself. It implies a positive judgement of the king's profile, that short after his mourned death, was given a legendary aura. This nevertheless did not always count with the Church's support. Some examples of the attributions to the king are: epical crussader against the infidel sarracins, epitomy of a hero, root of a glorious dinasty in Valencia and Mallorca, etc. And those were mere samples of the different meanings that the recorded effigies express. Meanings that offer an extraordinary vision of king Jacques I, although not always close to reality.

Keywords: Jacques the Conqueror, Saint George, Iconography, Monarchy, King's liturgy.

\section{Programas Ideológicos a través de la Imagem: algunos ejemplos de la Edad Media}

\author{
Marta Serrano Coll
}

\section{OBJETIVOS}

Dotado de una fuerte personalidad, el áurea legendaria del rey de Aragón Jaime I (12131276), a quien los anales de la historia bautizaron con el sobrenombre de El Conquistador, puede advertirse incluso en los momentos previos a su concepción, tildada por algunos de milagrosa. Su acertado gobierno y espléndido talante, según explican algunas de las fuentes medievales, tuvieron eco plástico principalmente en la iconografía generada después de su reinado, sobre todo a partir del siglo XIV a instancias, no pocas veces, de sus descendientes.

Medievalista online № 9 | Janeiro - Junho 2011 @ IEM - Instituto de Estudos Medievais 2 
El recorrido en imágenes que pretendo realizar ${ }^{1}$ abraza un arco cronológico de más de doscientos años que regalan, intermitentemente, evidencias plásticas sobre cómo fue visto y concebido el rey Jaime a lo largo del período medieval. Esta concepción, sobre todo ulterior y que denota una clarísima visión favorable hacia su figura, aunque fue favorecida muchas veces por el patrocinio de la propia monarquía, en ocasiones fue generada por otros organismos con el deseo de vincularse a la institución monárquica y, de esta manera, conseguir un mayor prestigio al tiempo que enaltecían su grado de notoriedad.

\section{LA CEREMONIA DE CORONACIÓN Y LAS EXEQUIAS REGIAS}

De extensión variable y condensadas en la ceremonia de coronación y en la liturgia de las exequias, ambas solemnidades constituyen los instantes que indican el principio y el final de un reinado.

Jaime I personifica un gobierno especialmente particular, pues no constan noticias sobre su coronación ${ }^{2}$. Bien es cierto que el mismo rey afirmó en su crónica que era rey por derecho $^{3}$, pero los hechos constatan que toda la vida aspiró a ser coronado por el Santo Padre ${ }^{4}$.

\footnotetext{
${ }^{1}$ Iconografía que fue analizada en SERRANO COLL, Marta - Jaime I el Conquistador. Imágenes medievales de un reinado. Zaragoza: Institución Fernando el Católico, 2008.

${ }^{2}$ Desclot advierte: "aquest enfant En Jacme fo ja cregut, que ben havia ja vint ans, [...] anà-se'n a Saragossa e llevà-se rei". DESCLOT, Bernat - "crònica" in SOLDEVILA, Ferran - Les quatre grans cròniques. Barcelona: Selecta, [1972], 1983³, cap. XI.

3 "Nós sóm rei d'Aragó, e havem-lo per nostre dret", JAUME I - "Libre dels feyts del rei en Jacme" in SOLDEVILA, 1972, pár. 29.

${ }^{4}$ Es bien conocida la descripción de la corona que ordenó realizar con motivo de su deseada coronación: "e que ja no en trobaria hom tan bona en Lió com aquella, car era feita ab aur et ab peres precioses que valia pus de cent míl.lia sous de torneses". JAUME I - Libre dels feyts..., pàr. 536.
}

Medievalista online $\mathrm{N}^{0} 9$ | Janeiro - Junho 2011 @ IEM - Instituto de Estudos Medievais 3 


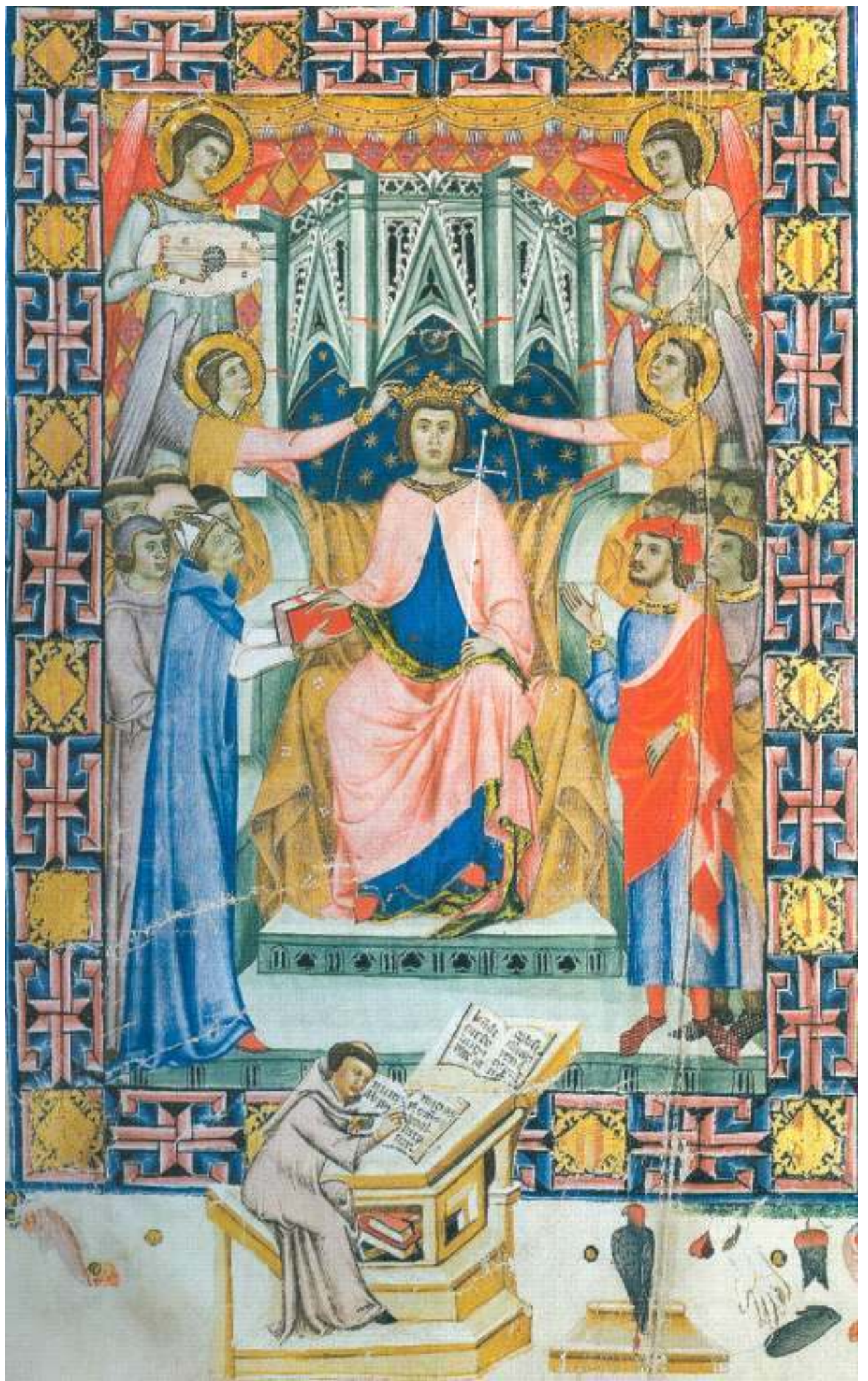

Fig. 1 Llibre de franqueses i privilegis del regne de Mallorca, fol. 13v. 1334. Arxiu del Regne de Mallorca 
[Fig. 1] Sólo nos consta una imagen que, supuestamente, ilustraría la coronación de Jaime I, representación que se encuentra en el Llibre de franqueses i privilegis del regne de Mallorca ${ }^{5}$ iluminado por el miniaturista identificado con Joan Loert ${ }^{6}$. Una viñeta a página entera del folio $13 \mathrm{v}$ presenta el momento durante el cual el Conquistador está siendo coronado por dos ángeles al tiempo que concede y jura las franquícias y privilegios del reino de Mallorca, representación inusual al combinar las dos ceremonias en una misma escena ${ }^{7}$. Bien es cierto que no hay nada que nos indique que sea él el respresentado, cuestión que puede hacer pensar en que aquí se alude al rei de Mallorca, a nivel genérico, tal y como defienden Gabriel Llompart e Isabel Escandell en un estudio reciente ${ }^{8}$ al considerar que la identificación con Jaime I entraría en contradicción con el hecho de que este rey nunca fue coronado. Que esta circunstancia no le privase de introducir la corona en la iconografía donde hasta entonces era inexistente es una de las razones, entre otras, que parecerían indicar que podría tratarse del rey Jaime quien, por "derecho de conquista", instauró este tipo de solemnidades en la isla.

Esta escena que deriva de la Maiestas sienesa ${ }^{10}$, es una imagen de poder que no hace sino evidenciar de plásticamente la voluntad y pretensión, por parte de la monarquía insular, de un supuesto carácter sacro: recordemos que por estas fechas la legitimidad de

\footnotetext{
5 Fue firmado en 1334 por el escribano Romeu des Poal. BOHIGAS, Pedro - La ilustración y la decoración del libro manuscrito en Cataluña. Contribución al estudio de la miniatura catalana. Barcelona: Asociación de Bibliófilos de Barcelona, 1960, vol. II, p. 96-97.

6 También llamado Joan Lloret según URGELL, Ricard - "Munificencia regia. Llibre de franqueses i privilegis del regne de Mallorca" in BANGO TORVISO, Isidro Gonzalo (Dir.) - Maravillas de la España Medieval. Tesoro sagrado y monarquía. I. Estudios y Catálogo. León: Junta de Castilla y León, Caja España, 2000, p. 129.

${ }^{7}$ Se llama la atención sobre esta cuestión en LLOMPART I MORAGUES, Gabriel y ESCANDELL I PROUST, Isabel - El llibre de franqueses i privilegis del regne de Mallorca. Estudi historicoartístic estudio todavía inédito que acompañará la edición facsímil de este libro. Desde aquí agradezco a Isabel Escandell que me facilitara el texto todavía por publicar.

${ }^{8}$ Ibidem.

${ }^{9}$ Para más detalles, PALACIOS MARTÍN, Bonifacio - "Los símbolos de la soberanía en la Edad Media. El simbolismo de la espada" in VII Centenario del Infante Don Fernando de la Cerda. Jornadas de Estudio. Ciudad Real: Instituto de Estudios Manchegos, 1976, p. 273-296. Más adelante se volverá sobre esta cuestión.

${ }^{10}$ Advertido por YARZA LUACES, Joaquín - "La pintura española medieval. El mundo gótico" in PÉREZ SÁNCHEZ, Alfonso E. (Dir.) - La pintura española, Milán: Electa, 1995, vol. I, p. 87. Ha vuelto a ponerlo de manifiesto en YARZA LUACES, Joaquín - "La miniatura en los reinos peninsulares medievales" in YARZA LUACES, Joaquín (Ed.) - La miniatura medieval en la Península Ibérica, Murcia: Nausícaä, 2007, p. 46-47.
} 
los reyes mallorquines ya estaba puesta en entredicho. Así, no es casual que esta figuración intente constatar a nivel iconográfico el origen místico del poder del soberano: de hecho, aquí los que coronan al rey son los ángeles: los delegados directos, y mensajeros, del poder celestial ${ }^{11}$.

Como ceremonia eurítmica a la de la coronación, encontramos la de las exequias que, no pocas veces, encontró eco iconográfico de carácter monumental. No fue el caso de Jaime I, cuya primera tumba fue una sepultura "muyt honrada" según expresión de la Crónica de San Juan de la Peña ${ }^{12}$. Consistía, como la de su abuelo Alfonso el Casto, en una sencilla urna de madera forrada de terciopelo o de damasco y claveteada de metales $\operatorname{preciosos}^{13} \mathrm{y}$, como la de su predecesor, se ubicaba en el presbiterio de la iglesia de Santa María de Poblet $^{14}$.

El cambio de localización y de estructura fue resultado de la voluntad de Pedro el Ceremonioso, quien sintió verdadera predilección por el Conquistador. Hacia 1366, de acuerdo con Josep Bracons ${ }^{15}$, se colocó la nueva sepultura del rey Jaime sobre un arco entre los pilares del crucero y fue representado, como especifican los documentos, con una yacente "esmaltada de vidre, semblant a la sepultura del dit senyor rei [en Pere], ab caps de chembranes et de dos pilars dobles de images et de tabernacles et de formes" $" 16$. En 1370, el Ceremonioso ideó una doble representación, motivo por el cual contrató, también con el maestro Cascalls, “dues ymages de pedra, a estatura, del rei Jacme,

\footnotetext{
${ }^{11}$ Aunque durante este período, afirmar el origen divino del poder áulico fue un objetivo casi obsesivo en el marco de las monarquías medievales: RAYNAUD, Christiane - "La réprésentation du pouvoir dans le langage iconographique de l'enluminure française au debut du XVème siècle" Razo. Cahiers du Centre d'Études Médiévales de Nice. Nice, núm. 9, (1989), p. 152. Sobre la evolución de la iconografía de la ceremonia de coronación, remito a SERRANO COLL, Marta - "El códice AGN B2 y la iconografía de coronaciones y exequias regias en la miniatura bajomedieval" in Ceremonial de Unción, Coronación y Exequias de los reyes de Inglaterra (AGN. Códices y Cartularios. B.2), vol. II. Estudios, Pamplona, Gobierno de Navarra e Institución Príncipe de Viana, 2008, p. 145-175.

${ }^{12}$ Crónica de San Juan de la Peña..., cap. 36.

${ }^{13}$ Fray Vicente de Prada afirma que sólo era de madera forrada con terciopelo negro: PRADA, Fray Vicente - Sepulcros de la casa $\mathrm{R}^{\mathrm{L}}$. de Aragon, Condes de Urgel, Duques de Segorbe, y Cardona, Varones, Señores de Vassallos, Cavalleros, Obispos, Abades, y otros muchos, que descansan, y eligieron sepultura en el Insigne y R. Monasterio de Nrā $S^{\mathrm{ra}}$. De Poblet, Orden del Cister. Elvcidados por un indigno Monge de dicho $\mathrm{R}^{\mathrm{L}}$. Monast ${ }^{\circ}$. Dedicados A la Concepcion Purissima de la Reyna y Emperatriz de los Cielos María $S^{\text {ra }}$. Nrā. Año 1692, Biblioteca de Poblet, Ms. Arm. VI. C. 19.39, fol. 4r.

${ }^{14}$ DEL ARCO Y GARAY, Ricardo - Sepulcros de la Casa Real de Aragón. Madrid: Instituto Jerónimo Zurita, Consejo Superior de Investigaciones Científicas, 1945, p. 186-188.

${ }^{15}$ BRACÓNS I CLAPÉS, Josep - "Operibus monumentorum que fiere facere ordinamus. L'escultura al servei del Cerimoniós" in Pere el Cerimoniós i la seva època. Barcelona: Anuario de Estudios Medievales, annex núm. 24, 1989, p. 219.

${ }^{16}$ ALTISENT, 1974, p. 274.
} 
besavi del senyor rei [...] ço és, una a figura e a manera de rey coronat [...] e altra, a figura e a manera de monge, ab son àbit vestit, e qui jau tinent corona reyal en son cap"17. Es decir, una con todos los ornamentos reales de acuerdo con el padre Finestres $^{18}$ y otra representado como monje en el lado que da a la sacristía vieja. También exhuma la documentación que la primera imagen que se esculpió para la sepultura de Jaime I se destinó, finalmente, a la tumba de Alfonso II $^{19}$, decisión que pone de manifiesto, y corrobora, contrariamente a lo que sucedía en otros ámbitos europeos, el escaso valor retratístico que por entonces se otorgaba a este tipo de figuraciones.

\section{LA IMAGEN DEL REY EN DOS SOPORTES LEGALES: LA NUMISMÁTICA Y LA SIGILOGRAFÍA}

Conocedor de su potencial y condicionado por la necesidad de organizar y unificar sus dominios, aunque dotándolos de cierta autonomía tras las recientes conquistas, el Conquistador se sumergió en una intensa labor iconográfica que, afectando a estos dos soportes jurídicos, reafirmaba su poder ante sus súbditos.

En el terreno numismático, rescató la tarea unificadora propia de su abuelo Alfonso y volvió a adoptarla en 1247 mediante una nueva acuñación de terno ${ }^{20}$ que seguía el modelo provenzal, es decir, busto coronado de perfil / cruz procesional, expedida en la ceca de Valencia y destinada a los territorios acabados de conquistar: Valencia y Mallorca. En 1258 decidió crear una nueva moneda barcelonesa con la cabeza del rey coronada para diferenciarla del doblenc. Interesante fue la gran cruz que introdujo en el

17 RUBIÓ I LLUCH, Antoni - Documents per a la història de la cultura catalana mig-eval (edició facsímil de l'any 2000). Barcelona: Institut d'Estudis Catalans, 1908, vol. I, doc. 235, p. 226-228. Y MARÉS DEULÒVOL, Federico - Las tumbas reales de los monarcas de Cataluña y Aragón del monasterio de Santa María de Poblet. Barcelona: Asociación de Bibliófilos de Barcelona, 1952, doc. 35, p. 183-185.

${ }^{18}$ No especifica más: FINESTRES Y DE MONSALVO, Jaime - Historia del Real Monasterio de Poblet, ilustrada con disertaciones curiosas sobre la antigüedad de su fundación, catálogo de abades y memorias cronológicas de sus gobiernos, con las de papas, reyes y abades generales del Císter tocantes a Poblet dividida en cinco libros (1753). Barcelona: Orbis, 1948, vol. III, p. 299.

19 “'...] que aquella ymage del dit rey Jacme, la qual lo dit maestre [Cascalls] havia ja feta [...] devia posar en una part del vas del senyor rey n'Amfos". MARÉS, 1952, doc. 35, p. 183-185.

${ }^{20}$ Llamada así por ser tres los marcos de plata que entraban en el riel para batirla: MATEU I LLOPIS, Felip - La moneda de los reinos de Valencia y Mallorca. Valencia: Anubar, 1977, p. 130.

Medievalista online № 9| Janeiro - Junho 2011 @ IEM - Instituto de Estudos Medievais 7 
reverso cantonada por anillos y puntos $^{21}$ pues, al anverso típico de la moneda provenzal, le añadía un nuevo reverso que cumplía la función de otorgar una nueva identidad a la acuñación. También introdujo cambios en la moneda aragonesa, los más importantes de los cuales se encuentran, igualmente, en el reverso: una gran cruz de doble travesaño campea por toda su superficie. Lazos familiares con León, donde Fernando II (11571188) había emitido un dinero muy similar, podrían ofrecer una explicación plausible a la adaptación de esta iconografía por parte del rey Jaime, aunque también la podrían explicar su matrimonio con Violante, hija de Andrés de Hungría, quien emitía piezas contemporáneas con este elemento en alguna de sus caras ${ }^{22}$. O, quizás, las intensas relaciones con Sicilia, fruto de las cuales fue el matrimonio de su primogénito con Constanza, hija de Manfredo, donde circulaban ducatis donde figuraba Roger II con su primogénito entre una cruz de doble travesaño ${ }^{23}$. Así, la característica de su política monetaria fue la adopción de un mismo tipo iconográfico en el anverso de todas sus emisiones, tipo que se mantuvo constante en casi todas las emisiones posteriore ${ }^{24}$ : la representación del monarca tocado con una visible corona, la insignia regia por excelencia. Por otro lado, el rey escogió diferentes reversos para identificar cada uno de los territorios en los cuales se batía moneda: cruz procesional en Valencia, cruz cantonada por anillos y tres puntos en Barcelona, y cruz de doble travesaño en Aragón, cruces que debieron de mantener el antiguo significado simbólico bizantino ${ }^{25} \mathrm{y}$, en consecuencia, deben de relacionarse también con las guerras de cruzada que el Conquistador protagonizó tan encarecidamente.

\footnotetext{
${ }^{21}$ Posiblemente adoptados de los sterling ingleses, concretamente los pertenecientes a Enrique III según MATEU I LLOPIS, Felip - Les relacions del Principat de Catalunya i els Regnes de València i Mallorca amb Anglaterra i el paral.lelisme monetari d'aquests països durant els segles XIII, XIV i XV. Castelló de la Plana: Societat Castellonenca de Cultura, 1934, p. 30.

${ }^{22}$ ENGEL, Arthur y SERRURE, Raymond - Traité de Numismatique du Moyen Age. Paris: Arnaldo Forni Editore, 1890, vol. II, p. 886-888.

${ }^{23}$ Esta moneda original fue introducida por Roger II en 1140. Aparece publicada en GRIERSON, Philip Monnaies du Moyen Age. Paris: Bibliothèque des Arts, 1976, figs. 236 y 137.

${ }^{24}$ De hecho, la persistente imagen generó que la documentación se refiriese a ellas con el nombre de coronats: MAROT I SALSAS, Teresa - "La moneda medieval, moderna i contemporània. Els bitllets" in BARRAL I ALTET, Xavier (Dir.) - Ars Cataloniae, Art de Catalunya. Barcelona: L'Isard, 1997, vol. 12, p. 263.

${ }_{25}$ Es de sobras conocido que la iconografía de inspiración cristiana ideada por Constantino remitía a sus preocupaciones políticas, con lo que supeditaba la fe a las necesidades del Estado. Más detalles en GRABAR, André - Las vías de la creación en la iconografía cristiana. Madrid: Alianza, [1979], 1994, p. 45 y sig.
}

Medievalísta online $N^{\circ} 9 \mid$ Janeiro - Junho 2011 ๑ IEM - Instituto de Estudos Medievais 8 
Programas Ideológicos a través de la Imagem: algunos ejemplos de la Edad Media - Marta Serrano Coll

Evidentemente, la incorporación de nuevos territorios también tuvo eco iconográfico en el terreno de la sigilografía, obsoleta conforme avanzaban las sucesivas conquistas ${ }^{26}$.

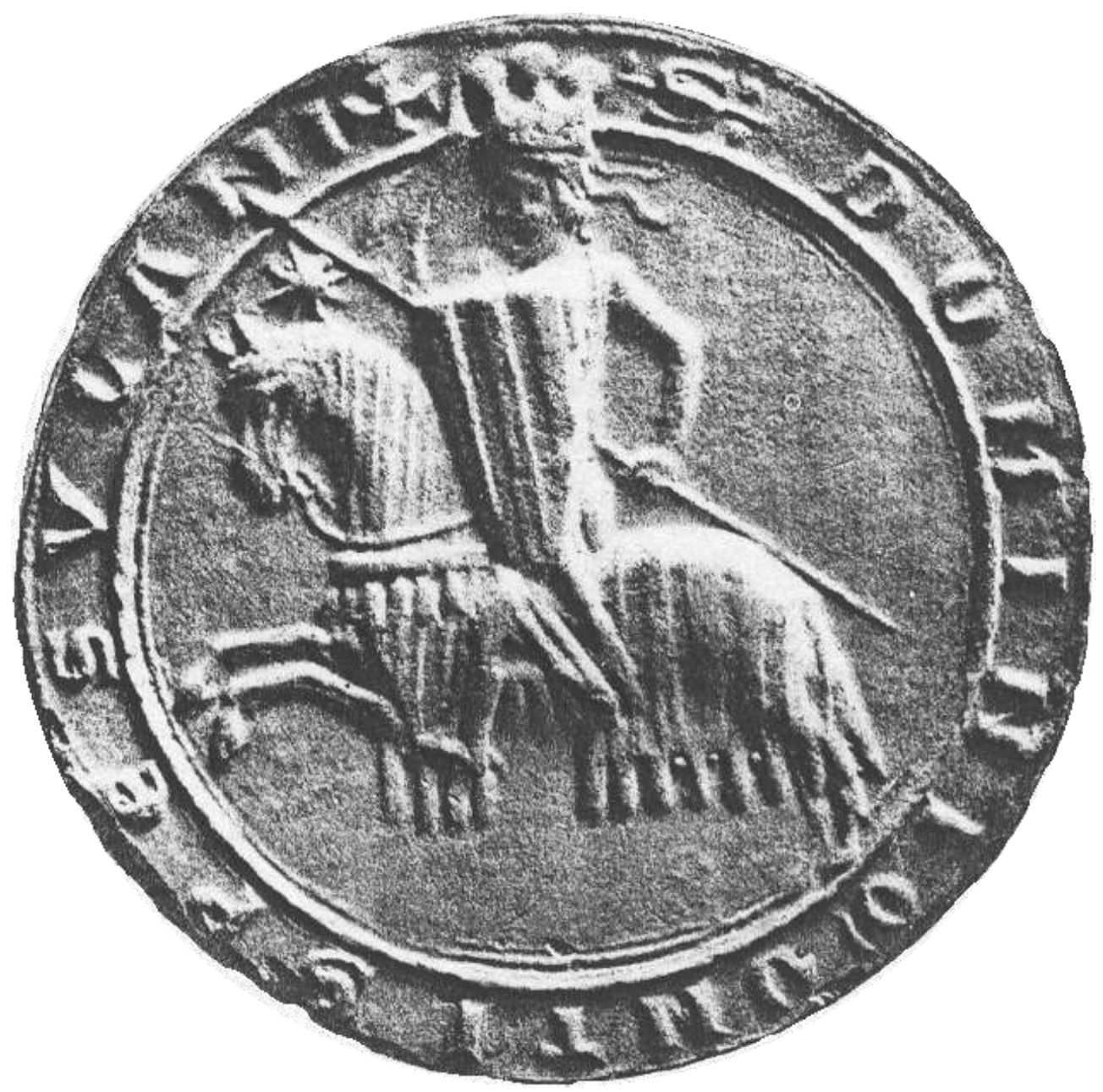

Fig. 2 Butlla de Jaume I Revers 1220 i 1226

\footnotetext{
${ }^{26}$ Ferran de Sagarra agrupó las piezas de Jaime I en tres períodos: desde los inicios de su reinado hasta la conquista de Mallorca en 1229, desde aquel año hasta la toma de Valencia en 1238 y, finalmente, desde entonces hasta la muerte del rey: DE SAGARRA Y SISCAR, Ferran - "Los segells del rey en Jaume I". Boletín de la Real Academia de Buenas Letras de Barcelona. Barcelona, núm. 29, (1908), p. 5. Mantuvo esta agrupación en DE SAGARRA Y SISCAR, Ferran - Sigil.lografia catalana. Inventari, descripció i estudi dels segells de Catalunya. Barcelona: Estampa d'Henrich, 1916-1932, p. 107.
}

Medievalista online $\mathrm{N}^{0} 9 \mid$ Janeiro - Junho 2011 @ IEM - Instituto de Estudos Medievais 9 
[Fig. 2] De todas las aportaciones iconográficas, quizás las más interesantes son las que se manifiestan en los reversos, pues su figuración ecuestre, por otra parte habitual en la iconografía del rey de Aragón desde tiempos de Alfonso II, se presenta por primera vez coronada y precedida por una estrella de seis u ocho puntas, indistintamente. Por lo que se refiere a la corona, el repertorio figurativo invita a afirmar que el cambio se debió, más que a un trasfondo ideológico enmarcado por los problemas de su anhelada y nunca conseguida coronación, a la inserción dentro de una corriente estética entonces imperante en la península y en el resto del continente ${ }^{27}$. Por lo que respecta a la estrella, que se mantuvo precediendo al caballero hasta tiempos de Juan I, las conclusiones parecen más dificultosas. La búsqueda de precedentes sigilares ha constatado que las piezas coetáneas que la muestran testifican la superioridad numérica de los sellos eclesiásticos referidos a Santa María, cosa que permite conjeturar que el astro podría poseer algún significado simbólico religioso a ella referido, suposición corroborada por la cantidad de oraciones y advocaciones que se refieren a María como stella ${ }^{28}$. Por otro lado, aunque no ha sido posible confirmarlo y no se han encontrado más referencias en este otro sentido, de acuerdo con una noticia de Francisco Javier de Garma, la estrella también podría referirse a las órdenes militares de caballería, sin la ayuda de las cuales gran parte de las victorias del rey Jaime no se habrían podido llevar a cabo ${ }^{29}$.

También resulta interesante la bula abierta entre 1231 y 1238 , pues se observan cambios en la utilización de las insignias. Por un lado el trono, que vuelve a asimilar la forma tradicional de escaño y abandona definitivamente el tipo curul que su padre había

\footnotetext{
${ }^{27}$ Fernando III (1230-1252) fue quien primero empezó a utilizar la corona sobre la cabeza del jinete en la Corona de Castilla y León, más o menos coetáneamente al inglés Enrique III (1216-1272). Véase DELAROCHE, Paul (Dir.) - Trésor de Numismatique et de glyptique ou Recueil général de médailles, monnaies, pierres gravées, bas-reliefs, etc. tant anciens que modernes. Les plus intéressants sous le rapport de l'art et de l'histoire. Sceaux des rois et reines d'Angleterre. Paris: Didier et C ${ }^{\mathrm{ie}}$ LibrairesÉditeurs, 1858, lám. IV, sellos núm. 2 y 3.

${ }^{28}$ El códice del siglo XII conservado en el Archivo de la Corona de Aragón (Còd. Ripoll núm. 193), lo aservera. Transcrito en SINUÉS RUÍZ, Prbo., Atanasio - "Advocaciones de la Virgen en un códice del siglo XII". Analecta Sacra Tarraconensia. Revista de Ciencias Histórico-eclesiásticas. Barcelona, núm. XXI, (1948), p. 11.

29 “En España tuvo principio por los años 1190 la Militar Caballería de Trujillo, cuya duración fue tan corta, que hallamos se agregó a la de Calatrava, el de 1196 con orden del rey don Alfon so VIII; su divisa era una estrella de plata, y su instituto acompañar la persona real en todas las jornadas": DE GARMA Y DURÁN, Javier - Adarga catalana. Arte y heráldica y prácticas reglas del blasón, con ejemplos de las piezas esmaltes y ornatos de que se compone un escudo, interior y exteriormente. Barcelona: Orbis, 1954 [1753], p. 67.
} 
utilizado en sus piezas de plomo, transformación con consecuentes, pues el solio curul no volverá a verse en la sigilografía posterior. Por otra parte la espada, bien colocada verticalmente o, en las piezas de 1255-1273, reposando verticalmente sobre sus rodillas, que vió aumentado su protagonismo al sustituir al cetro ${ }^{30}$ a raíz, quizás, de la mencionada potenciación de su función como signo de soberanía ${ }^{31}$.

\section{EL MINISTERIUM REGIS}

Bajo su gobierno, y condicionado por la adquisición de nuevos territorios, se intensificó el desarrollo político, institucional y legislativo mediante la compilación de códices jurídicos ya existentes y a través de la redacción de otros nuevos que, con el tiempo, fueron de nuevo copiados recibiendo decoración iluminada, a veces, de calidad extraordinaria. En consecuencia, numerosas imágenes lo presentan a manera de autor con tipos compositivos muy similares y ciertamente monótonos que a menudo engañan pues, en ocasiones, se enriquecen con otros contenidos que otorgan a la icografía un significado más profundo del que se podría sospechar a primera vista.

El primer cartulario del que conviene hacer mención es la copia que contiene los Furs de la ciutat e regne de Valencia, en concreto el ejemplar realizado por Boronat Pera, notario del rey Alfonso el Benigno, en $1329^{32}$. El original, inserto en el furor legalis de la cristiandad tras las recientes conquistas ${ }^{33}$, fue fruto de la decisión de Jaime I que empezaba a utilizar por sí mismo el poder legislativo. Haciendo gala de su personalidad como gran promotor del derecho, convertía a sus dos nuevos reinos en entidades independientes a las que, además de dar moneda y sistema de pesos y medidas propios, les otorgaba exclusivos privilegios. Fue firmado y jurado el 11 de abril de 1261 y en su redacción, según Gunnar Tilander, podría haber intervenido el obispo de Huesca Vidal

\footnotetext{
${ }^{30}$ Insignia condenada al olvido en la sigilografía del Conquistador. El cambio fue efímero, pues su hijo la recuperó y se convirtió en un elemento permanente de todos los sellos de sus sucesores.

${ }^{31}$ Sobre este tema, PALACIOS MARTÍN, 1976, p. 285. También dedica un apartado especial a las dos insignias en PALACIOS MARTÍN, Bonifacio - La coronación de los reyes de Aragón. 1204-1410. Aportación al estudio de las estructuras políticas medievales. Valencia: Anubar, 1975, p. 81-88.

${ }^{32}$ O Bononato de Piedra: DOMÍNGUEZ BORDONA, Jesús - El arte de la miniatura española. Madrid: Plutarco, 1932, vol. II, p. 208.

33 AHUIR Artur y PALAZÓN, Alicia - Història de la literatura en llengua valenciana. Segle XIII, València: Diputació de València, 2001, p. 213.
} 
de Cañellas ${ }^{34}$, dato relevante, pues podría sospecharse que sus miniaturas toman como modelo la decoración que ilustraba la obra capital que se nos ha conservado de este eclesiástico: el llamadao In excelsis Dei thesauris. Entronizado, se nos presenta el monarca a manera de autor, tipo iconoráfico que se desarrolló en el Imperio Romano y que se difundió por Europa a través de los carolingios y los otonianos sin apenas variación $^{35}$. La función de esta forma compositiva era, como advertía André Grabar, reemplazar al soberano en perona $\mathrm{y}$, de la misma manera que lo hacía el retrato grabado en un sello, validar el documento que ilustraba ${ }^{36}$. Son diversas las miniaturas que responden a esta misma tipología, esté el soberano entronizado o en pie: las que encontramos decorando algunos de los pergaminos de el Llibre de franqueses i privilegis del regne de Mallorca, el Llibre dels Usatges de Ramón Ferrer i el Llibre Verd I, el Tercer Llibre Verd, els Usatges de Barcelona, el Llibre de privilegis de Cervera, o el Llibre de privilegis i ordinacions dels hortolans de Sant Antoni así lo ponen de manifiesto.

Dentro de esta misma tipología, mucho más interesantes resultan las que muestran el consenso, pues la decisión real tenía que resultar de la reunión del consejo. Como se sabe, la Corona de Aragón disponía, desde antuvio y por derecho propio, de las Cortes: un mecanismo a través del cual todas las decisiones gubernativas estaban sometidas al consenso. La documentación exhuma que Jaime I intensificó su celebración regular, cuestión que se pone de manifiesto en las crónicas y que también se constata en la iconografía. Del repertorio compilado destacan las que se encuentran en el Llibre de franqueses i privilegis del regne de Mallorca, al Llibre de franquees de Malorcha o las de los diferentes ejemplares de los Usatges i constitucions de Catalunya, pero quizás la más espectacular es la que se encuentra en el folio 75r del llamado Tercer Llibre Verd de Barcelona y que encabeza las constituciones de paz y tregua otorgados por Jaime I, quien, convenientemente enfatizado, se flanquea por obispos y civiles.

\footnotetext{
34 TILANDER, Gunnar - Vidal Mayor, traducción aragonesa de la obra «In excelsis Dei thesauris» de Vidal de Canellas. Lund: Hakan Ohlssons, 1956, vol I, p. 21.

${ }^{35}$ Aunque se remonta hasta el mundo egipcio. FERNÁNDEZ GONZÁLEZ, Etelvina - "El retrato regio en los Tumbos de los tesoros catedralicios" in BANGO (Dir.), 2000, p. 47

${ }^{36}$ GRABAR, André - La iconoclastia bizantina. Dossier arqueológico. Madrid: Akal, colección Arte y Estética, 1998 [1984], p. 68.
} 
Programas Ideológicos a través de la Imagem: algunos ejemplos de la Edad Media - Marta Serrano Coll

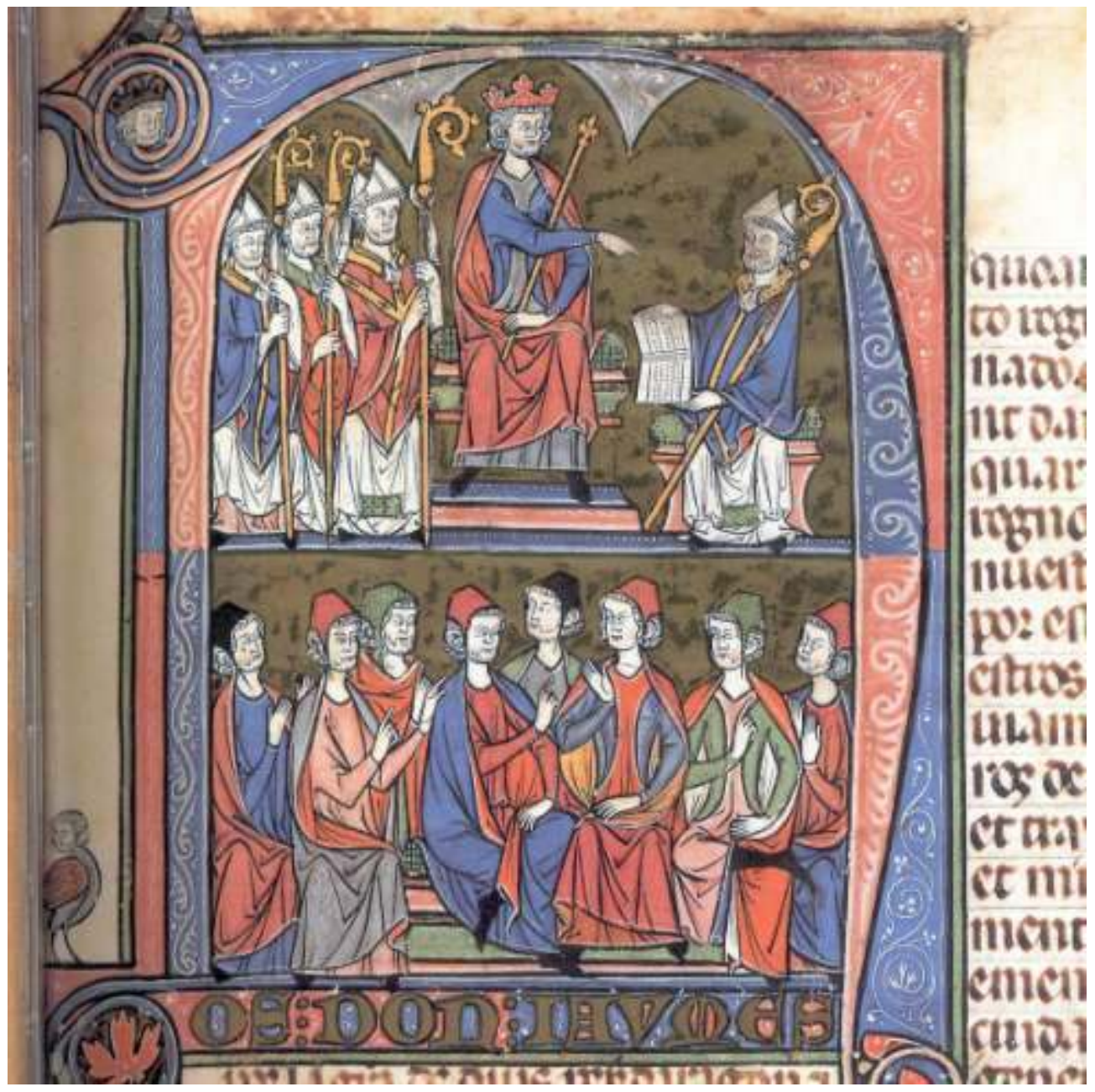

Fig. 3 In excelsis Dei thesauris, fol. 1r. 1270-1290.

J. Paul Getty Museum, Santa Mónica (California) 
[Fig. 3] Dentro del Ministerium Regis, la administración de justicia fue una tarea esencial, pues el rey, fuente de derecho y entendido entonces como la propia ley viviente, ejercía la función judicial. Evidentemente, en la práctica era muy extraño que ejerciese la justicia directamente, motivo por el cual se había generado un complejo engranaje de funcionarios y otros administrativos que actuaban en nombre del rey y velaban por proteger a los benefactores y castigar, con todo el peso de la ley, a los maliciosos. Es dentro del In excelsis Dei thesauris, también conocido como Vidal Mayor, donde encontramos las primeras y únicas representaciones medievales que retratan al rey de Aragón, a nivel genérico, como juez. Ordenamiento jurídico que constituye uno de los más importantes cartularios del siglo XIII, fue fruto de la iniciativa de Jaime I para acabar, en las Cortes de Huesca de 1247, con las diversidades forales existentes para consolidar un sistema jurídico unificado instaurando en la Corona lo que Luis González ha definido como un "proceso de territorialización empírica del derecho"37. La versión que aquí se analiza se trata de una tercera compilación que no se sabe si es una versión romance del In excelsis o una compilación comentada por el obispo de Huesca, pero nos interesa por las magníficas y diversas representaciones que, deudoras del arte oficial romano ${ }^{38}$ y estudiadas con minuciosidad por M. Carmen Lacarra ${ }^{39}$, ilustran el texto que acompañan de inmediato. La del folio 1r muestra al Conquistador en el preciso instante de ordenar la compilación. Verdaderamente fue él quien decidió organizar la nueva recopilación de leyes, pues no es sino a él a quien corresponde esta función ${ }^{40}$ : de él proviene la justicia y, en la línea de la búsqueda de la consolidación del poder real por encima de barones y grandes eclesiásticos, es quien posee el derecho de su aplicación ${ }^{41}$. Así, dentro de una gran inicial, se nos efigia el Conquistador quien, de acuerdo con los miembros de su corte, también representados en el registro inferior, encarga a Vidal de Cañellas la ejecución

37 GONZÁLEZ ANTÓN, Luis - "Los fueros, las cortes y el justicia de Aragón” in Aragón. Reino y Corona. Centro Cultural de la Villa de Madrid. Del 4 de abril al 21 de mayo de 2000. Zaragoza: Gobierno de Aragón, 2000, p. 119.

${ }^{38}$ Sobre esta cuestión remito al estudio de GRABAR, 1994.

${ }^{39}$ Quien, además, ofrece un estado de la cuestión sobre la obra. LACARRA DUCAY, M ${ }^{\text {a }}$ Carmen - "Las miniaturas del Vidal Mayor: estudio histórico-artístico" in Vidal Mayor. Estudios. Huesca: Excelentísima Diputación Provincial, Instituto de Estudios Aragoneses, 1989, p. 115-166.

40 “por los quoales el dito regno sea governado": Vidal Mayor Edición facsímil..., 1989, fol. 1r, 2 a col.

${ }^{41}$ Remito a GONZÁLEZ ANTÓN, 2000, p. 119. 
del compendio legal en presencia de altos dignatarios eclesiásticos, todos ellos identificados gracias a las fuentes escritas ${ }^{42}$.

Otra faceta del rey Jaime alude a la misericordia, virtud que practicó en numerosas ocasiones, tal y como indican los renglones de las crónicas medievales, evidentemente cristianas $^{43}$, y que ha tenido un excepcional eco iconográfico en el conocido como "códice rico" de las Cantigas de Santa María elaboradas a instancias de Alfonso X entre 1257 y 1284 . Dentro de la viñeta, se nos muestra, encabezado por la sentencia "C. os mouros pedíron mercee al rei don James Daragon", al Conquistador con toda fastuosidad y magnificencia haciendo acto de clemencia. Hay quien aseguraría que son los caprichos del artista los que han hecho que la fisonomía de Jaime y de Alfonso sea tan diversa: el primero efigiado con cabellos y larga barba canosa, muy al contrario que el castellano, de apariencia mucho más joven. No fue tanta la diferencia de edad entre ambos monarcas, por lo que cabría encontrar una razón para esta particularidad iconográfica. Quizás explicaría su aspecto senil el hecho que el de Aragón fuese suegro del castellano o, quizás, el recuerdo que de que el rey don Jaime había personificado un reinado de más de sesenta años, algo nada habitual en la época. Sobre esto, volveremos más adelante.

\section{LA DEVOCIÓN DEL REY DON JAIME}

Es cierto que no todos los soberanos se preocuparon de igual modo por la liturgia, aunque tampoco no dudaron en confiar a las plegarias mnásticas y a las generosas donaciones, es verdad, la salvación de sus almas. Consta, documental e iconográficamente, que Jaime I experimentó todas estas posibilidades, aunque pese estas actuaciones de carácter piadoso, fue también muy consciente de la protección divina dispensada hacia su persona: su crónica abunda en detalles que corroboran este sacro amparo desde su infancia hasta su edad adulta; tan consciente fue de esta condición que no dudó en numerosas ocasiones en poner su vida, intencionadamente, en peligro.

\footnotetext{
${ }^{42}$ Vidal mayor..., fol. $1 \mathrm{r}$.

${ }^{43}$ Las árabes lo muetran como un verdugo y lo mencionan, no pocas veces, como "el tirano de Barcelona", Sobre la visión de los musulmanes vencidos hacia la figura de Jaime I remito al trabajo de FURIÓ, Antoni - El rey Conquistador. Jaime I: entre la historia y la leyenda. Valencia: Bromera, 2007, p. 62 .
} 
Algunas imágenes, como la exhibida en el folio 1r de los Fori et privilegia Valentiae, muestra al rey en actitud piadosa, esto es, arrodillado, con las manos unidas y mirando hacia la parte superior derecha, justo donde emerge el rostro de Dios Padre, tipo compositivo que ya se observa, al menos, hacia finales del siglo XI. No obstante, la iconografía, contrariamente a lo que podría parecer, no es puramente devota. Teniendo en cuenta que el propietario del manuscrito, y quizás también su promotor, fue Berenguer March, canónigo de Valencia y Barcelona, y sacristán desde 1309 a $1334^{44}$, podría sospecharse que lo que se quiso intentar con la imagen fue dar un carácter perpetuo a los privilegios a través de la figuración orante del rey in perpetuum, o bien evidenciar plásticamente la práctica de la invocación, que este manuscrito ofrece en sus primeras lñineas, mediante la cual se confería al texto de un áurea de sacralidad ${ }^{45}$.

También ligada al ambiente eclesiástico, conviene mencionar la miniatura del primer folio del Liber instrumentorum encargado por Hug de Llupià i Bages, presidente del cabildo de la Seo valenciana entre 1396 y $1427^{46}$, que presenta a Jaime I ante la Virgen María y el Niño con la intención de prometer la dotación a la nueva sede: "Instrumentorum quo dominus rex promisit dotare ecclessiam", según refiere el texto ${ }^{47}$. Señalaba Marisa Melero ${ }^{48}$ que en el anacronismo de representar juntos a un rey del siglo XIII, conquistador de Valencia y primer mecenas de la iglesia levantina, y a un obispo que, además de ser el promotor del cartulario, ejerció su cargo a caballo entre los siglos XIV y XV, explica el significado simbólico de la imagen: con esta representación se buscaba legitimar y reafirmar plásticamente el compromiso de dotación de la iglesia de Valencia que había asumido, in perpetuum, Jaume I.

Dentro de este apartado deben incluirse las representaciones del Conquistador como miles Christi, es decir, las que lo presentan como férreo luchador contra el enemigo

\footnotetext{
${ }^{44}$ Según unos datos que, añadidos en el siglo XIX, se incluyen en el folio 117 del manuscrito. Además, también fue tesorero de los reyes de Aragón. Más detalles en La ciudad de la memoria. Los códices de la catedral de Valencia. La ciutat de la memòria. Els còdexs de la catedral de València, Consorci de museus de la comunitat valenciana, Valencia, 1997, p. 179.

45 Esta nueva lectura de este tipo de imágenes fue iniciada por GARDIN, Alessandra - "Presenza di immagini religiose in codici laici" in CECCANTI, Melania y CASTELLI, Maria Cristina (Dirs.) - Atti del III Congresso di Storia della miniatura. Il codice miniato. Rapporti tra codice, testo e figurazione. Firenze: Leo S. Olschiki, 1992, p. 375-385.

${ }^{46}$ DOMÍNGUEZ BORDONA, Jesús - Miniatura. Madrid: Plus Ultra ediciones, 1958, vol. XVIII, p. 165 y BOHIGAS, 1960, vol. II.II, p. 18.

47 ALEIXANDRE, Francisca - "El gobierno de la sociedad. El govern de la societat [Liber Instrumentorum]" in La ciudad..., 1997, p. 181.

${ }^{48}$ MELERO MONEO, Marisa - "La Virgen y el rey" in BANGO (Dir.), 2000, p. 424.
} 
infiel, habitualmente durante el curso de una batalla, para exaltar plásticamente sus virtudes caballerescas y sus buenos resultados derivados de la protección divina, cuestión que reforzaba lo que Bonifacio Palacios describió como "la imagen del rey como elegido directamente por la divinidad y por tanto soberano de sus reinos"

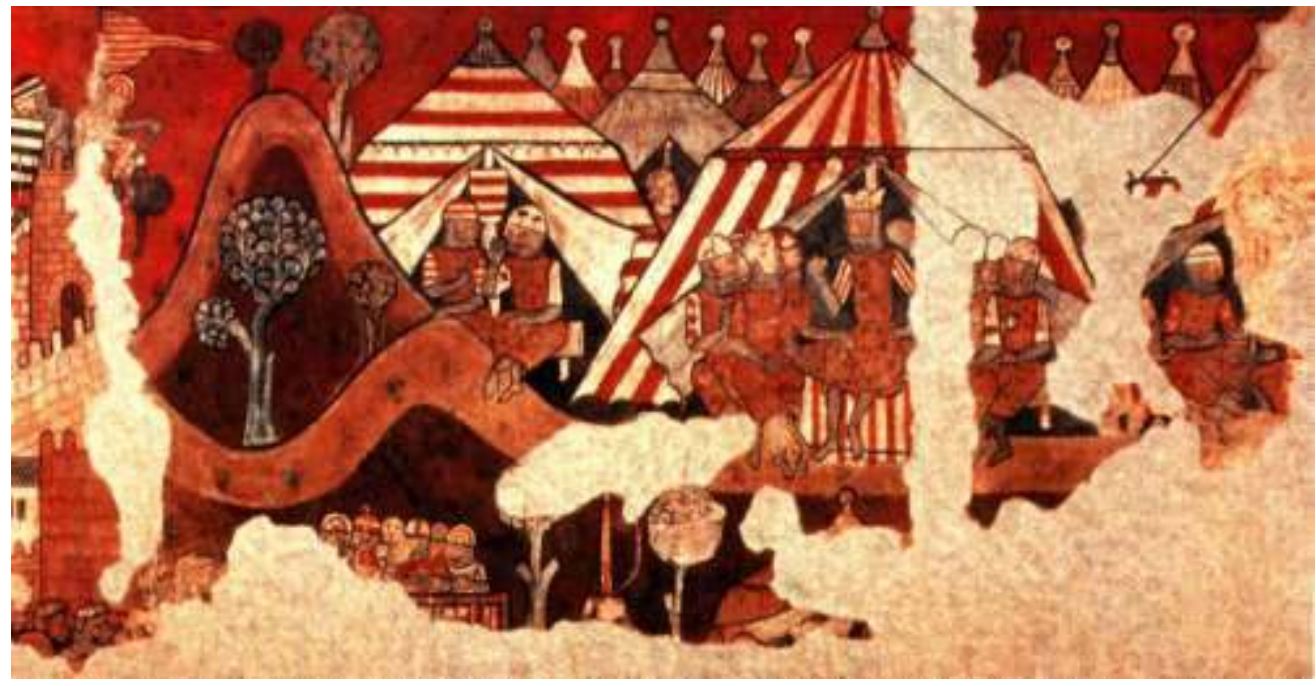

Fig. 4 Pintures del Palau Aguilar, carrer Montcada de Barcelona. Cap el 1285-1290. Museu Nacional d'Art de Catalunya

${ }^{49}$ PALACIOS MARTÍN, Bonifacio - "Imágenes y símbolos del poder real en la Corona de Aragón” in ). $\mathrm{XV}^{\circ}$ Congreso de Historia de la Corona de Aragón. El poder real en la Corona de Aragón (siglos XIVXVI). Zaragoza: Gobierno de Aragón. Departamento de Educación y Cultura, 1996, vol. 1, p. 203. 
[Fig. 4] Las Pinturas del Palacio Aguilar, que evidencian un género iconográfico que tenía en el ámbito civil un medio de inspiración y un lugar de expresión que no se había olvidado desde época romana, muestran los sucesivos episodios de la conquista de Mallorca llevada a cabo por Jaime I en 1229. Fechadas hacia 1285-1290, célebres y muy estudiadas, el fragmento que más nos interesa es la escena de la preparación del asalto a Madina Mayurqa, capital de la isla. Dentro de la tienda real, destaca la efigie del Conquistador rodeado de distinguidos personajes ${ }^{50}$. Facilmente identificado por su regia ubicación y por su corona, que reviste gran parte de su cervellera también palada, su indumentaria, compuesta por gonió o cota de malla cubierta por el perpunt, indica que nos encontramos ante una escena de carácter bélico que debió de ser muy frecuente durante la campaña insular: el Llibre dels Feyts nos describe más de un consejo previo a la ofensa ${ }^{51}$ y nos aporta otros datos también reflejados en el programa iconográfico: además del conocido desacuerdo del conde de Empúrias, nos informa del apretado campamento y de la actitud de confianza que algunos hombres de confianza le tenían, como es el caso de Gilabert de Cruïlles, que apoya cordialmente su brazo sobre la pierna del Conquistador. Estos murales conmemoran los episodios de la conquista de la isla de Mallorca por parte del rey don Jaime que se conocían al detalle por las crónicas y por otros relatos épicos redactados para afirmar una especie de ideología oficial de la corte y de la dinastía, expresiones literarias que, con este tipo de representación plástica, había encontrado, de acuerdo con Miquel Coll, una nueva vía de difusión ${ }^{52}$. Pero sería necesario relacionar esta figuración con la reconquista que, de la isla, había protagonizado, en 1285, es decir, muy poco antes de la ejecución de esta decoración, el infante Alfonso, quien disfrutaba de Dolça de Caldes como amante, dato relevante si se tiene en cuenta que se han encontrado emblemas de esta familia acompañando el ciclo $^{53}$ : la escena de Jaime I que, seguramente, halagaría al rey al rememorar las gestas

\footnotetext{
${ }^{50}$ Entre otros, Gilabert de Cruïlles, el obispo de Barcelona Berenguer de Paloy, Ramón de Centelles y Nunyo Sans: AINAUD, 1969, p. 22.

${ }^{51}$ JAUME I, Libre dels feyts..., párs. 67, 68, 69, 81.

52 Este autor supuso la existencia de un ciclo de miniaturas que podrían haber ilustrado la crónica de Desclot: COLL I ALENTORN, Miquel - Historiografia. Obres. Barcelona: Publicacions de l'Abadia de Montserrat, Curial, 1991, vol I. Citado en SERRA DESFILIS, Amadeo - "Ab recont de grans gestes. Sobre les imatges de la història i de la llegenda en la pintura gòtica de la Corona d'Aragó". Afers. Fulls de Recerca i Pensament. Calarroja, núm. 41, vol. XVII, (2002), p. 18.

${ }^{53}$ AINAUD, 1969, p. 22-24.
} 
de su antepasado ${ }^{54}$, se configuraba como el precedente inmediato al acontecimiento y, muy probablemente, además lo legitimaba.

Dejando al margen la supuesta efigie que del Conquistador se encuentra en los murales del Palacio Real de Barcelona, cuya identificación todavía hoy resulta dudosa ${ }^{55}$, el siguiente conjunto interesante es el del castillo de Alcañiz, fortificación que, de origen incierto, exhibe importantes restos pictóricos que evocan la conquista de Valencia por parte de Jaime $\mathrm{I}^{56}$, quizás como intento de rememorar las gestas de un pasado caracterizado por la lucha contra los musulmanes y la afirmación del poder de la monarquía ${ }^{57}$ junto con la voluntad de la orden militar de Calatrava, propietaria de la fortaleza desde $1179^{58}$, de exhibirse con un tono de exaltación por su participación en estas empresas bélicas contra el elemento sarraceno. De todas las escenas ${ }^{59}$, quizás la más problemática ha sido la del osculum que culmina la cara sur del primer arco, donde dos individuos se dan un beso en la boca, el único igualador, pues requiere que los dos participantes se encuentren en el mismo nivel: se trataría de un osculum pacis. Aunque se han apuntado otras hipótesis ${ }^{60}$, la más convincente continua siendo la propuesta de Carlos $\mathrm{Cid}^{61}$, quien afirmó que la escena mostraría el final de la disputa que, sobre el reino de Navarra, habrían mantenido Jaime I y su yerno Alfonso X. De acuerdo con este contencioso bélico $^{62}$, ambos reyes portan, con variantes, arnés de guerra: cervellera y sobreseñal palado bajo el cual se mostran el ausberg, las calzas de malla y los escarpines para el aragonés, y cervellera coronada y defensa de visibles launas para el castellano. No hay ninguna duda de que se trata de un rey de Aragón, pues su señal real,

\footnotetext{
${ }^{54}$ Señalado per SERRA, 2002, p. 18.

${ }^{55}$ Por la iconografía y la heráldica. Estado de la cuestión en SERRANO, 2008, p. 189-192.

${ }^{56}$ Francesca Espanyol indicó que podrían rememorar acontecimientos de las campañas contra Granada protagonizadas por Jaime II y Alfonso IV: ESPAÑOL BERTRÁN, Francesca - "Las pinturas murales del castillo de Alcañiz". Al-qanniš. Boletín del Taller de Arqueología de Alcañiz. Extra de divulgación. El cerro de Pui Pinós y el castillo de Alcañiz. Una presencia histórica. Alcañíz, (1993), p. 30-32.

${ }^{57}$ SERRA, 1993, p. 30-32.

${ }^{58}$ CID PRIEGO, Carlos - "Las pinturas murales del castillo de Alcañiz". Goya. Revista de Arte. Madrid, núm. 46, (1962), p. 274-277.

${ }^{59}$ Todas analizadas en SERRANO, 2008, p.192-208.

${ }^{60}$ LACARRA DUCAY, M Marmen - Las pinturas murales góticas del castillo de Alcañiz. Restauración. Zaragoza: Ministerio de Cultura, Diputación General de Aragón, Caja Inmaculada, 2005.

${ }^{61}$ CID PRIEGO, Carlos - "Las pinturas murales del Castillo de Alcañiz". Teruel. Separata. Teruel, núm. 20, (1958), p. X.

${ }^{62}$ Teobaldo I de Navarra (1234-1253) determinó que sus dominios e hijos tuviesen como tutor a Jaime I hasta la mayoría de edad del primogénito. Una vez difunto, el castellano aprovechó la ocasión para invadir el reino, deseo frustrado al intervenir el rey de Aragón. Para más información remito a la síntesis CID, 1958, p. 66.
} 
aunque no lleve corona, inunda toda su indumentaria. Caso contrario resulta el de Castilla y León que, necesariamente, ha de hacer visible esta insignia para permitir su correcta identificación, pues su vestimenta no permite carga herláldica.

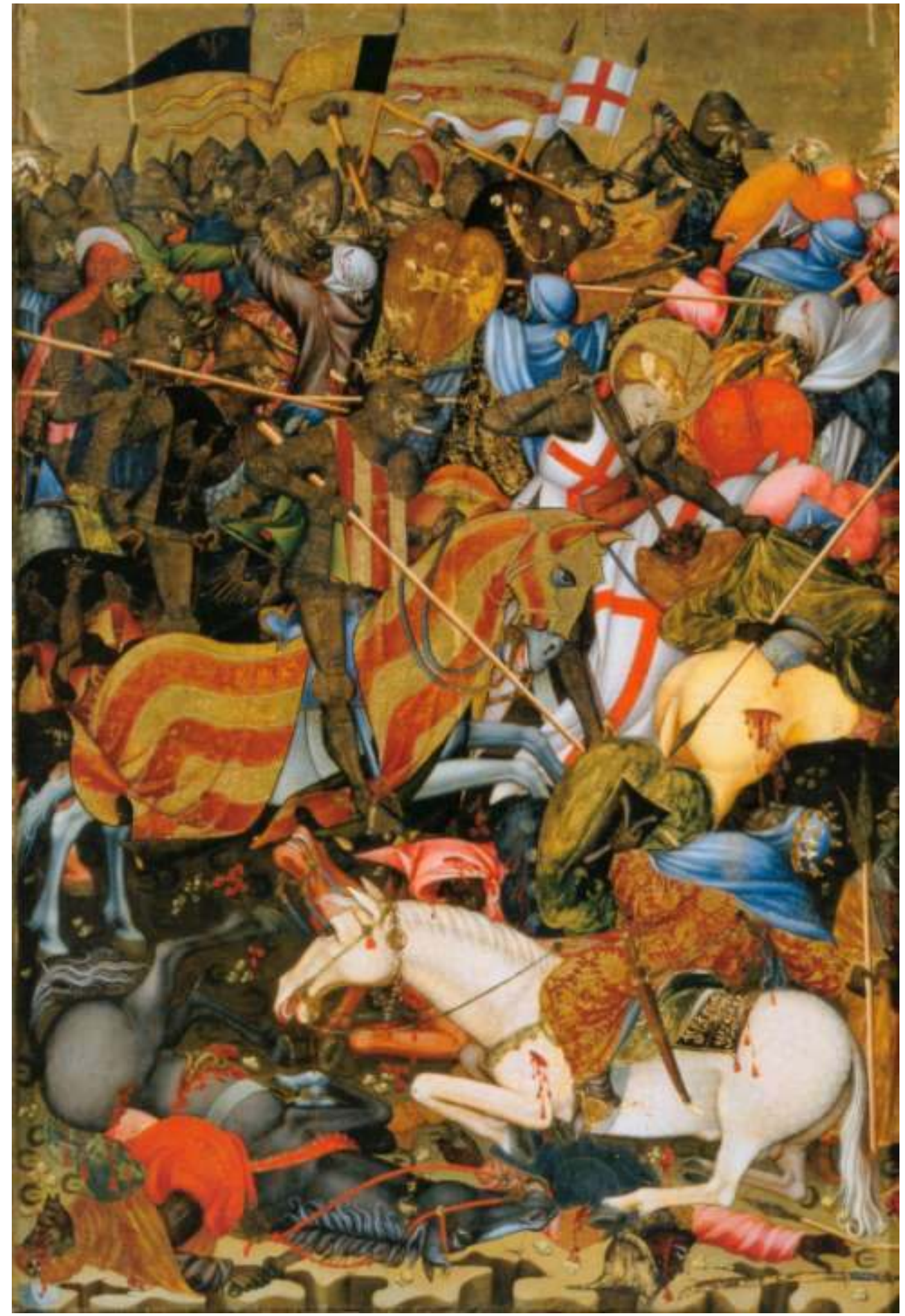

Fig. 5 Retaule de Sant Jordi o del Centenar de la Ploma, atribuït a Marzal de Sax. Cap el 1410-1420. Victoria and Albert Museum. Londres 
[Fig. 5] Pero, quizás, de todo el repertorio que presenta al rey Jaime como feroz cruzado contra el infiel, las más sorprendentes son las que lo muestran bajo el amparo divini, evidentemente siguiendo un tipo iconográfico que se encuentra en la órbita de la imagen caballeresca del rey santo que, algunos decenios antes del año 1000, se había generalizado por el viejo continente. Quizás, de estos episodios, el más conocido sea el auxilio que, por parte de San Jorge, el Conquistador recibió durante un importante combate. Y es que, quieren las crónicas, este venerable ayudó al rey Jaime y a sus huestes durante la conquista de Valencia ${ }^{63}$. La primera obra que se refiere a este hecho prodigioso es el retablo de San Jorge o del Centenar de la Ploma que, atribuido a Marzal de $\operatorname{Sax}^{64}$, fue realizado hacia el 1410-1420 para la Casa de Confraternitat del Centenar de la Ploma ${ }^{65}$. De todo el conjunto, destaca la que ha sido identificada como la batalla del Puig gracias a la cual Jaime I llegó a conquistar la ciudad de Valencia. Sólo la Crónica de San Juan de la Peña menciona este acontecimiento milagroso, líneas que aseguran, sorprendentemente, que el rey no participó en el combate ${ }^{66}$. Probablemente, esta "licencia" se debe a la mitificación que sufrió su figura poco después de su muerte; de acuerdo con Amadeu Serra, la admiración que sus contemporáneos sentían hacia su figura pronto se convirtió en devoción para las generaciones sucesivas ${ }^{67}$ : el retablo del Puig sería la primera muestra plástica conservada de esta evolución. Igualmente, como apuntaba Joan Molina ${ }^{68}$, las representaciones que ostentaban el especial favor de San

\footnotetext{
${ }^{63}$ No fue la primera vez que este delegado divino intercedía por el rey. Según antiguos escritos de carácter áulico, Pedro I (1094-1104) ya se había beneficiado de su ayuda en una de sus ofensivas contra la entonces ciudad musulmana de Huesca. No es casualidad que la primera referencia de este auxilio se encuentre en la Crónica de San Juan de la Peña, redactada a instancias de Pedro el Ceremonioso.

${ }^{64}$ Sobre la problemática atribución remito a KAUFFMANN, C. M. - Catalogue of Foreign Paintings. Before 1800. London: Victoria and Albert Museum, 1973.

${ }^{65}$ Adyacente a la iglesia de Sant Jordi. Ibidem, p. 184.

66 “"...] non tan solament ayudavan a él quando a vía batallas con los moros, mas encara ayudavan a sus vasallos quando por él se combatian con los moros; porque se dize que como él avies enviado algunos nobles et caballeros en el regno de Valencia [...] en un pueyo qui agora es clamado Santa María del Puyg et toda la morisma vinies contra ellos en la batalla, qui entre ellos fue muyt gran, les apareció Sant Jorge con muytos cavalleros de parada qui los ayudó a vencer la batalla, por la qual ayuda ningún christiano no hi murió". Crónica de San Juan de la Peña..., cap. 35, líns. 230-239.

${ }^{67}$ Lo sintetizó con la expresión "la conexión entre los hilos de la crónica histórica y la hagiográfica popular”: SERRA, 2002, p. 24-25. Muy interesante es el artículo de NARBONA VIZCAÍNO, Rafael "Héroes, tumbas y santos. La conquista en las devociones de Valencia Medieval". Saitabí. Revista de la Facultad de Geografía e Historia de la Universidad de Valencia Valencia, núm. 46, (1996), p. 293-319.

68 MOLINA I FIGUERAS, Joan - "La ilustración de leyendas autóctonas: el santo y el territorio". Analecta Sacra Tarraconensia. Revista de Ciencias Históricoeclesiásticas, Barcelona, núm. 70, (1997), p. 5-24.
} 
Jorge en las batallas contra los musulmanes fortalecían el protagonismo de la monarquía y, entre todos sus componentes, a Jaime I: el más poderoso, popular y entonces rodeado por un aura beatífica. Pero, además, conviene remarcar que lo que se aceptaba como cierto es que San Jorge había auxiliado al soberano para la toma de Mallorca y de Valencia, precisamente los reinos en los que Jaime I se consideraba como rey por derecho de conquista y por los que, entendía, no debía rendir homenaje a nadie, especialmente a las jerarquías eclesiásticas. Es decir, debería sospecharse que en el origen de la leyenda se escondía una evidente justificación divina con el fin de suplantar el reconocimiento eclesiástico que, en principio y a través de la ceremonia de coronación, le era exigido al monarca para ejercer con pleno derecho su soberanía ${ }^{69}$. A pesar de que las instituciones eclesiásticas no reconocieron este socorro divino y no apoyaron la difusión de este prodigio, las evidencias iconográficas indican que el milagro fue asumido y celebrado a lo largo del siglo XV; el retablo analizado lo ha puesto de manifiesto, así como otras obras como el retablo dedicado a San Jorge de Xèrica datado hacia el $1423^{70}$, o la desaparecida muestra en pergamino que pintó Gaspar Bonet en $1484^{71}$. Caso idéntico en significado pero al mismo tiempo diferente al ceñirse más a las fuentes documentales su iconografía, fue el de Mallorca, donde el santo, conforme a Jaime I, también habría intervenido en su favor durante la conquista ${ }^{72}$. Reflejado en la predela del retablo de san Jorge de Pere Nisart, fechado hacia $1470^{73}$, vincula la conquista de Mallorca con la participación del santo gracias a la identificación de la ciudad a través de la puerta de Bab el Kofol como escenario.

\footnotetext{
${ }^{69}$ Sobre esta cuestión remito a NARBONA, 1996, p. 293-319. Sobre la utilización-manipulación de la hagiografía con finalidades propagandísticas, véase MOLINA, 1997, en especial a partir de la p. 18.

${ }^{70}$ Se conserva en el Museo de su Ayuntamiento, y ha sufrido una restauración que, en mi opinión, es excesiva.

${ }^{71}$ La única referencia del cual se encuentra en PUIG I CADAFALCH, Josep y MIRET I SANS, Joaquim - "El Palau de la Diputació General de Catalunya". Anuari de l'Institut d'Estudis Catalans. Barcelona, vol. III, (1909-1910), p. 385-480, después recordada por DURÀN I SANPERE, Agustí - Barcelona i la seva història. Barcelona: Curial. Documents de cultura, 1975, vol. III, p. 217

72 "E segons que els sarraïns nos contaren, deïen que viren entrar primer a cavall un cavaller blanc ab armes blanques; e açò deu ésser nostra creença que fos sent Jordi, car en estòries trobam que en altres batalles l'han vist de crestians e de sarraïns moltes vegades". JAUME I, Libre dels feyts..., pàr. 84.

${ }^{73}$ Se ha conservado el documento contractual de 1468. GUDIOL RICART, José - Pintura gótica. Madrid: Plus Ultra, 1955, vol. IX, p. 295.
} 


\section{EL RECUERDO Y EL LINAJE}

Con la función de rememorar unos hechos, aunque con el velado objetivo de seleccionar e imponer una visión concreta por parte de sus promotores, las crónicas se configuraron como uno de los géneros literarios más notables de la Edad Media: en la Corona de Aragón se generó diversa literatura de este tipo, incluso surgida, o acometida bajo la supervisión, de la mano de dos de sus monarcas: Jaime I y Pedro el Ceremonioso, gran admirador de su predecesor. [Fig. 6] Del Libre dels feyts del rei en Jacme, realitzat amb la voluntat de convertir-se en specula principum ${ }^{74}$, se conservan diversas versiones, si bien la que incumbe al presente artículo es la encargada por el abad Ponç de Copons a Celestí Destorrens en 1343 según indica el explicit ${ }^{75}$. Una serie de miniaturas decoran el manuscrito y ofrecen la imagen de Jaime I en diversas actitudes. Interesante es la del folio 1r, donde el monarca aparece orante: "pregàs per nos al seu fill que ens donàs lo tort que li teníem"76, suplica el rey don Jaime en sus primeras líneas. El "tort” podría referirse a las diversas disensiones entre el monarca y la iglesia, discrepancias que le comportaron incluso una excomunión. Pero también podría relacionarse con lo que las Crónicas anónimas de Sahagún definieron como el "maldito e escomulgado ayuntamiento" protagonizado por sus predecesores Alfonso I y Urraca de Castilla y que la dinastía de Aragón arrastraría como un estigma desde octubre de 114, cuando fue promulgada la anulidad por consanguinidad de los esposos ${ }^{77}$. A partir del folio 20r se suceden el resto de letras capitales, muy similares entre si, y, en el verso del 27, se nos presenta la viñeta que más ha llamado la atención por parte de los historiadores donde, directamente relacionada con el texto que se inicia a continuación, se muestra el banquete en el cual el mercader Pere Martell convenció al rey y a los altos magnates para conquistar la isla de Mallorca. Además de la desaparecida figuración que, en el folio 65r de este mismo códice, exhibía a Jaime I entrevistándose con Blasco de Aragón

\footnotetext{
74 "Lleixam aquest libre per memòria a aquells qui volran oir de les gràcies que Nostre Senyor nos ha feites, e per dar exempli a tots los altres hòmens del món, que facen ço que nós havem feit de metre sa fe en aquest Senyor qui és tant poderós". JAUME I, Libre dels feyts..., cap. 1

${ }^{75}$ Se ha verificado que la redacción más antigua de la crónica debería datarse entre 1313 y 1327: DE RIQUER, Martí y VALVERDE, José María - Historia de la literatura universal. Barcelona: Planeta, 1968, vol. I, p. 351. Existe una versión facsímil en Libre dels feyts del rey en Jacme. Edición facsímil del manuscrito de Poblet (1343) conservado en la Biblioteca universitaria de Barcelona. Barcelona: Universidad de Barcelona, 1972.

${ }^{76}$ JAUME I, Libre dels feyts..., pàr. 1.

${ }^{77}$ Josep Ma Pujol llamó la atención sobre esta cuestión en su conferencia «La utilización de las crónicas como elemento legitimador», pronunciada dentro del simposio Símbolos e imágenes. La búsqueda de modelos en el mundo tardoantiguo y medieval, Universitat Rovira i Virgili. Tarragona, marzo de 2005.
} 
y el Maestro del Hospital Hug de Fullalquer en el castillo de Alcañiz y que iniciaba el capítulo referente a la conquista de Valencia, constan otras efigies del rey don Jaime en otras crónicas, como los dibujos marginales de la Crónica de Jaime I copiada e iluminada por Juan de Barbastro en $1380^{78}$, o la miniatura del Llibre en llatí i en mallorquí qui tracte de la vinguda del rei D. Jaume el Conquistador a estas islas, per el P. Pera Marsili, dominico, son cronista ${ }^{79}$, que debería de leerse como una glorificación de esta orden.

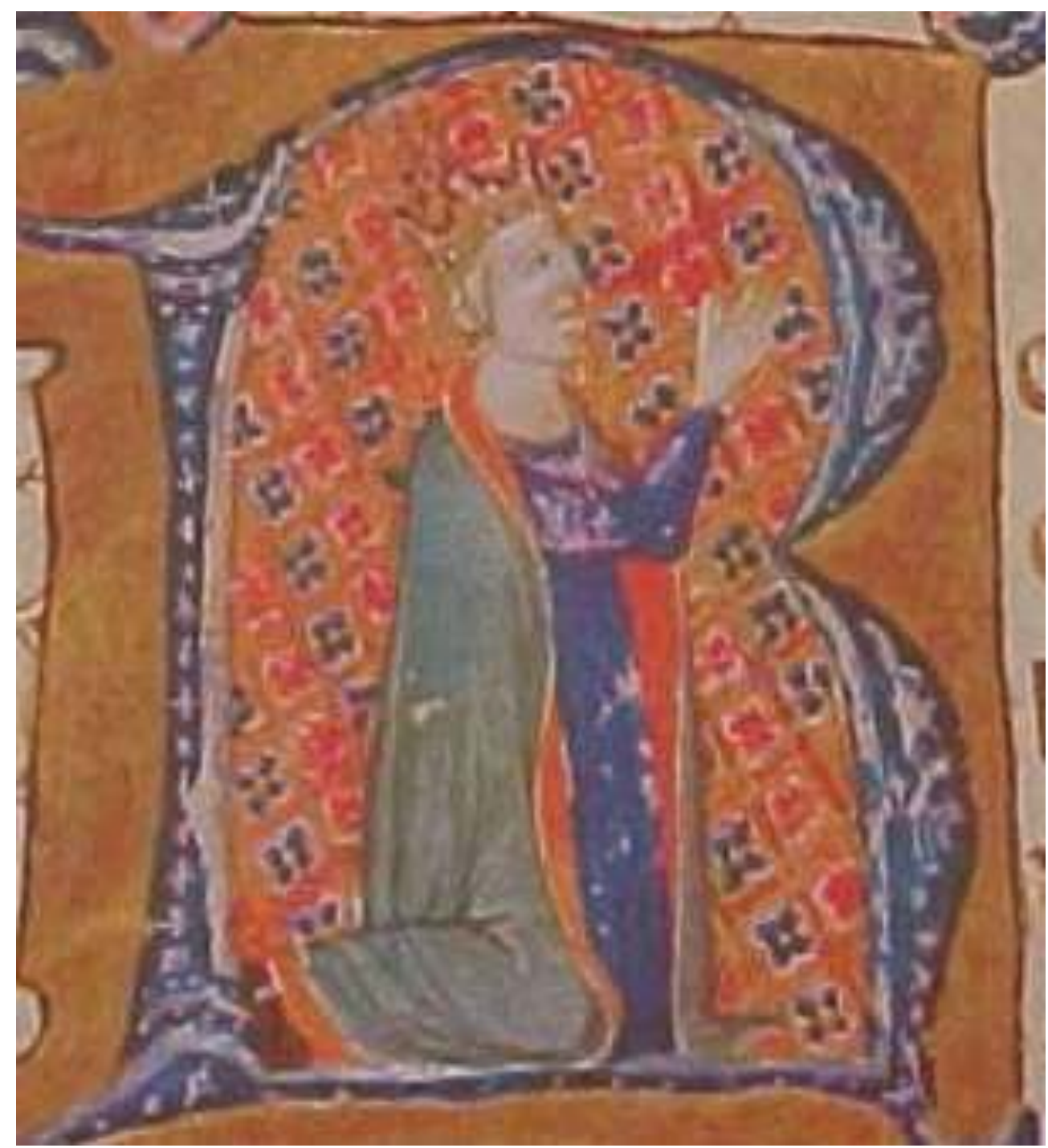

Fig. 6 Libre dels feyts del rei en Jacme, fol. 1r.Cap el 11343 Biblioteca de la Universitat de Barcelona

${ }^{78}$ Se conserva en la Biblioteca de Catalunya. La primera representación marginal, en el folio 33v, presenta a un fraile predicador con una filactelia en una de sus manos.

79 Jaime II había concedido al fraile Pere Marsili 130 sueldos barceloneses de los derechos del sello real para escribir el Liber gestorum de Jaume I: RUBIÓ, 1908, vol. I, doc. XLVII, p. 58. 
Pero la imagen del rey Conquistador también fue utilizada en las genealogías: catálogo de individuos que establecía el orden de sucesión de un linaje o de una dinastía a través de filiación o parentesco ${ }^{80}$. La Corona de Aragón conserva interesantes ejemplares ilustrados, algunos incluso programados con el fin de justificar o legitimar algún hecho político como, por ejemplo, la ocupación de un territorio: la desaparecida espada de coronación que el Ceremonioso encargó al platero valenciano Pere Bernés en 1360 debería leerse en esta clave ${ }^{81}$. Con esta comisión, el soberano ennoblecía con plena consciencia esta insignia, atributo que había adquirido un profundo significado por su amado y valorado predecesor, Jaime I. Es probable que en el transfondo de esta empresa artística tuviese mucho que ver la "re-conquista", también por las armas, del reino de Mallorca a instancias del Ceremonioso y, del mismo modo, los intentos de emulación por parte de este monarca de su glorioso antecesor: con ella conseguía equipararse de nuevo con el glorioso Jaime al otorgar a sus herederos una espada emblemática para el día de la investidura que ejercería el mismo papel que, el fatal día de la muerte del Conquistador, jugó la espada Tisó ${ }^{82}$.

\footnotetext{
${ }^{80}$ Cito a BEAUNE, Colette - Les manuscrits des rois de France au Moyen Age. Le miroir du pouvoir. Paris: Bibliothèque de l'Image, 1989, p. 146.

${ }^{81}$ El soberano quería que esta insignia fuese "pus bell e pus rich e pus soptil" possibles, "mas en special volem que en la behina a defora haia de I cap al altre .XIX. esmalts qui sien en manera fets que en cascu puxa esser feta una figura de rey o de comte. Car en los dits esmalts volem fer fer les figures dels reys d Arago e comtes de Barchinona passats e la nostra". El documento se firmó en Tarazona el 28 de febrero de 1360: RUBIÓ, 1908, vol. I, doc. CXCIII, p. 191-192.

82 “Añade [...] Pedro Marsilio por relación de los que se hallaron presentes, que [...] tomó el rey [Jaime I] la espada que tenía a la cabecera de su cama, y la dio de su mano al infante diciéndole que tomase aquella espada, con la cual por la virtud de la diestra divina siempre había sido vencedor, y la llevase consigo y obrase varonilmente": DE ZURITA, Jerónimo - Anales de Aragón. Zaragoza: Institución Fernando el Católico, [1572], 1980, llib. III, cap. CI. Este episodio también se relata en la Crónica de San Juan de la Peña...., cap. 35, 266-268.
} 
Programas Ideológicos a través de la Imagem: algunos ejemplos de la Edad Media - Marta Serrano Coll

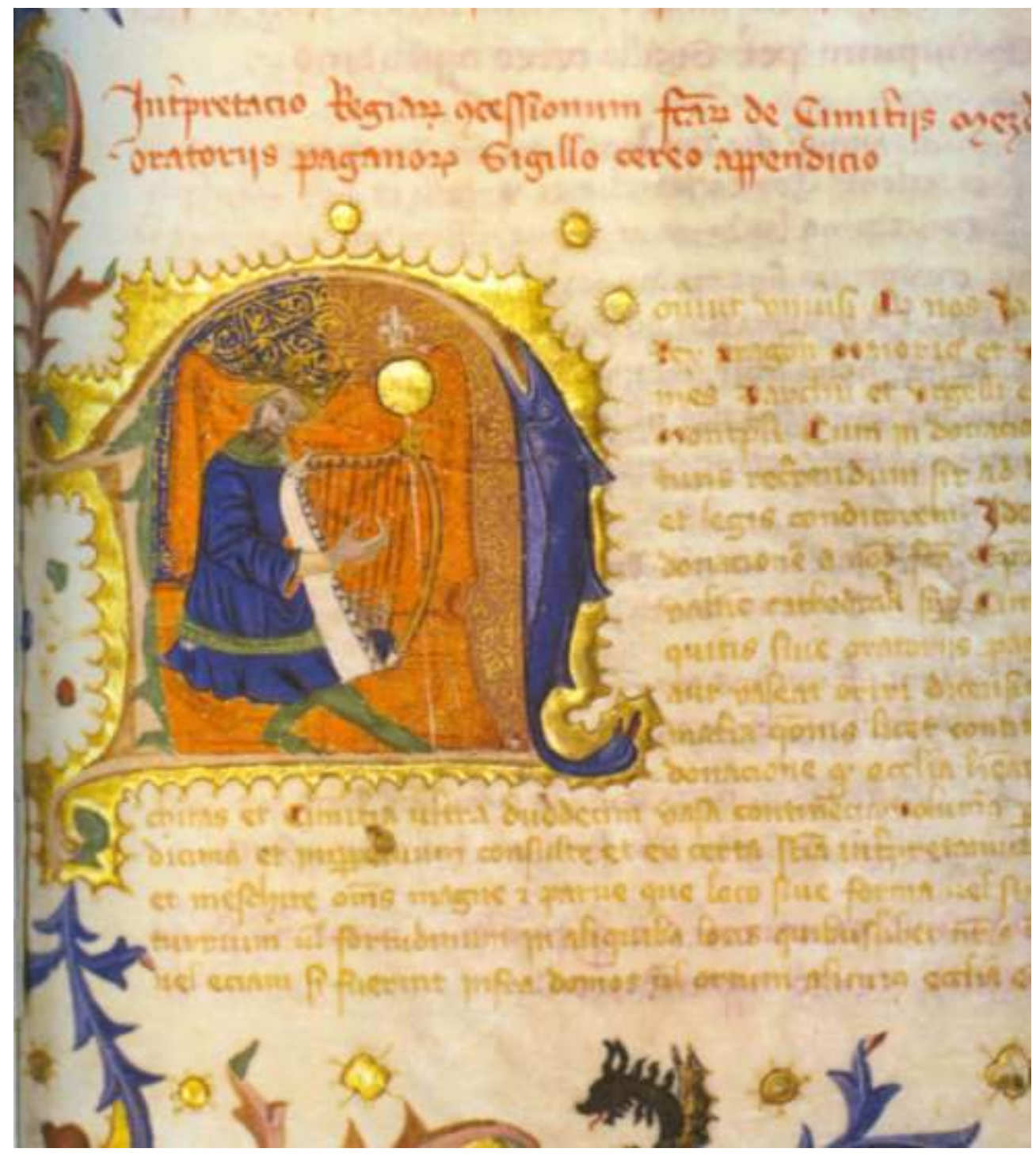

Fig. 7 Privilegiorum Regni Valentiae, fol. 1r. 3er 1/3 Segle XIV Arxiu Municipal d'Alcira 
[Fig. 7] Especial atención merece el Aureum Opus, libro que contiene los privilegios concedidos al reino de Valencia desde Jaime I a Pedro IV en su parte más antigua ${ }^{83}$ y que fue realizado en el último tercio del siglo $\mathrm{XIV}^{84}$. Iluminado con una serie de iniciales, sorprende la primera capital dedicada a Jaime I, pues nos lo muestra sentado y tocando el arpa, como si fuese el rey David, modelo de rey guerrero y, por tanto, de apropiada analogía respecto a este soberano que destinó gran parte de su vida a luchar contra el elemento musulmán y engrandecer sus dominios. Es posible que la identificación del Conquistador con el soberano de Israel, apasionado servidor de su Dios y gran rey de su pueblo, tenga la función de enaltecer a la dinastía en tierras de Valencia, pues las siguientes iniciales representan, como si se tratase de una verdadera genealogía a cada uno de sus sucesores, sin excepción, hasta el Ceremonioso, de manera que el Conquistador, primer monarca de Valencia, asimilado aquí con el rey veterotestamentario, se convierte en el punto de arranque de una glorificada saga ${ }^{85}$.

Pasando por alto las cuatro tablas de madera policromada de la sala del Consell de Valencia realizadas por Gonçal Peris ${ }^{86}$, Joan Moreno i Jaume Mateu hacia el 1427, en una de las cuales se ha querido identificar a Jaime I (en mi opinión erróneamente ${ }^{87}$ ), y que son muestra de la imitación, por parte de las instituciones gubernativas civiles de los modelos decorativos palatinos que evidenciaban el culto a los grandes hombres ${ }^{88} \mathrm{y}$ el gobierno municipal de una importante ciudad, en este caso Valencia, se concluirá este repertorio [Fig. 8] con la efigie que, de Jaime I, orna el conocido Rollo genealógico de Poblet $^{89}$ realizado hacia los años $1409-1410^{90}$. Con una composición que deriva del

${ }^{83}$ LAIRÓN PLÀ Aureliano J. y VERCHER LLETÍ, Salvador - Guia de l'Arxiu Municipal d'Alzira. Alzira: Ajuntament d'Alzira, 1998, p. 21.

${ }^{84}$ VILLALBA DÁVALOS, Amparo - "Los comienzos de la miniatura valenciana. Domingo Crespí". Archivo Español de Arte [Madrid], núm. XXXI, (1958), p. 179.

${ }^{85}$ Esta lectura fue expuesta en Trujillo en 2005 y publicada en SERRANO COLL, Marta - "La imagen como instrumento: el rey al servicio del códice, el códice al servicio del rey" in Libros con arte, arte con libros. Cáceres: Junta de Extremadura y Universidad de Extremadura, 2007, p. 661-663.

${ }^{86}$ Joan Aliaga advierte que la documentación no habla de Gonçal Peris, sino de Gonçal Sarrià: ALIAGA MORELL, Joan - Els Peris i la pintura valenciana medieval. València: Alfons el Magnànim, Institució Valenciana d'Estudis i Investigació, 1996, p. 92.

${ }^{87}$ Por falta de espacio, abordaré, profundizaré y justificaré esta cuestión en un próximo trabajo.

${ }^{88}$ ADHÉMAR, Hélène - Portraits français. XIVe - XVIe siècles. Paris: F. Hazan, 1950.

${ }^{89}$ Existe la edición facsímil Genealogia dels Comtes de Barcelona i Reis d'Aragó. València: Patrimonio Ediciones, 1997, acompañado por el estudio de GIMENO BLAY, Francisco y SERRA DESFILIS, Amadeo - Representar la dinastía: el manuscrito genealógico del monasterio de Poblet. Este rollo ha sido identificado con la "carte plegada en un tros de basto ab un tros de sendat vert on son tots los Reys D arago e comtes de Barchinona figurats" que se cita en el inventario de Martín I realizado a instancias de la reina Maria después de la muerte de su esposo: MASSÓ TORRENTS, Jaume -"Inventari dels bens 
modelo de las genealogías bíblicas ${ }^{91}$, esta serie dinástica ${ }^{92}$ debe ser entendida dentro de la política de prestigio y del marco de exarcerbación dinástica insertas en las actuaciones que inició Martín I para glorificar la dinastía ${ }^{93}$, quizás con tintes melancólicos al ser consciente de la extinción, con su muerte, de su célebre saga. Este pergamino ofrece una imagen de Iacme Rey que, muy estereotipada, lo efigia con una fisonomía anciana. Este semblante debe relacionarse con la longevidad del monarca qe, probablemente, conocía el miniaturista: justo al lado del anillo que lo rodea puede leerse "LXVII ayns", dato que alude a su edad y no a los años de su gobierno. El mismo Conquistador se vanagloriaría, en las líneas de su crónica, de su dilatado reinado: a punto de morir, en Alcira proclamaba: "Nostre senyor nos havia fet regnar al seu serviï pus de seixanta anys, mes que no era en memoria, ne trobava hom que negun rei, de David o de Salomó ençà, hagués tant regnat”, comparándose con estos dos reyes míticos del Antiguo Testamento.

mobles del Rey Martí d'Aragó". Revue Hispanique. Recueil consacré a l'étude des langues, des littératures et de l'histoire des pays castellans, catalans et portugais. Paris, vol. XII, (1905), p. 495. Citado en SERRA DESFILIS, Amadeo - "La historia de la dinastía en imágenes: Martín el Humano y el rollo genealógico de la Corona de Aragón”. Locus Amoenus. Bellaterra, núm. 6, (2002-2003), p. 58, n. 2.

90 Josefina Planas considera que, al incluirse la efigie de Martín el Joven, el códice debería ser anterior al 25 de julio de 1409: PLANAS BÁDENAS, Josefina - El esplendor del gótico catalán. La miniatura a comienzos del siglo XV. Lleida: Estudi General, Edicions de la Universitat de Lleida, 1998, p. 192.

${ }^{91}$ Sobre este modelo y su adaptación a las genealogías principescas remito a MARTÍNEZ DE AGUIRRE ALDAZ, Javier Miguel - "En torno a la iconografía de la familia en el occidente medieval" in DE LA IGLESIA DUARTE, José Ignacio (Coord.) - La familia en la Edad Media. Nájera: Instituto de Estudios Riojanos, 2000, p. 434.

92 Siguiendo a SERRA, 2002-2003, p. 58.

93 Además de este rollo, encargó un Breviari, la copia de la Cronica Regum Aragonum et comitum Barchinone procedente de San Juan de la Peña, la continuación de la Crónica de los reyes de Aragón y condes de Barcelona y otras actuaciones políticas, como la protagonizada en las cortes de Perpiñán el 26 de enero de 1406 y referida en ALBERT, Ricard y GASSIOT, Joan (Eds.) - Parlaments a les corts catalanes. Barcelona: Barcino, 1928, p. 59, citado en PLANAS, 1998, p. 61, n. 33. 


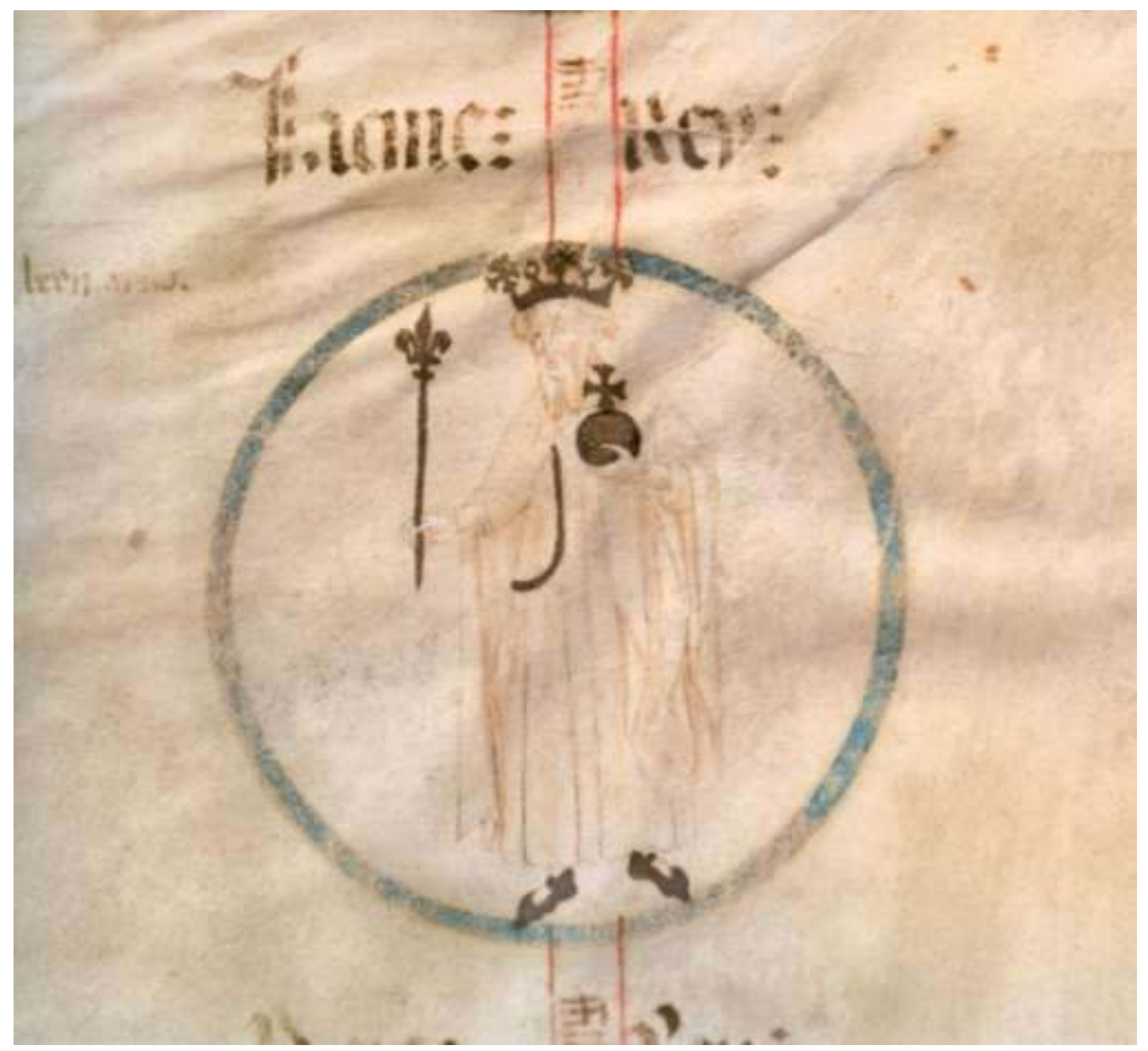

Fig. 8 Genealogia de Poblet Cap el 1409-1410 Biblioteca del Monestir de Poblet (Tarragona) 
Programas Ideológicos a través de la Imagem: algunos ejemplos de la Edad Media • Marta Serrano Coll

\section{BIBLIOGRAFIA:}

ADHÉMAR, Hélène - Portraits français. XIVe - XVIe siècles. Paris: F. Hazan, 1950.

AHUIR Artur y PALAZÓN, Alicia - Història de la literatura en llengua valenciana. Segle XIII, València: Diputació de València, 2001.

ALBERT, Ricard y GASSIOT, Joan (Eds.) - Parlaments a les corts catalanes. Barcelona: Barcino, 1928.

ALEIXANDRE, Francisca - "El gobierno de la sociedad. El govern de la societat [Liber Instrumentorum]" in La ciudad de la memoria. Los códices de la catedral de Valencia. La ciutat de la memòria. Els còdexs de la catedral de València. Consorci de museus de la comunitat valenciana, Valencia, 1997, p. 181.

ALIAGA MORELL, Joan - Els Peris i la pintura valenciana medieval. València: Alfons el Magnànim, Institució Valenciana d'Estudis i Investigació, 1996.

BANGO TORVISO, Isidro G. (Dir.) - Maravillas de la España Medieval. Tesoro sagrado y monarquía. I. Estudios y Catálogo. Real Colegiata de San Isidoro. León. 18 de diciembre de 2000 al 28 de febrero de 2001, Junta de Castilla y León, Caja España, León.

BARRAL I ALTET, Xavier (Dir.) - Ars Cataloniae, Art de Catalunya. Barcelona: L'Isard, 1997, vol. 12.

BEAUNE, Colette - Les manuscrits des rois de France au Moyen Age. Le miroir du pouvoir. Paris: Bibliothèque de l'Image, 1989.

BOHIGAS, Pedro - La ilustración y la decoración del libro manuscrito en Cataluña. Contribución al estudio de la miniatura catalana. Barcelona: Asociación de Bibliófilos de Barcelona, 1960, vol. II.

BRACÓNS I CLAPÉS, Josep - “Operibus monumentorum que fiere facere ordinamus. L'escultura al servei del Cerimoniós" in Pere el Cerimoniós i la seva època. Barcelona: Anuario de Estudios Medievales, annex núm. 24, 1989, p. 209-243.

CID PRIEGO, Carlos - "Las pinturas murales del castillo de Alcañiz". Goya. Revista de Arte. Madrid, núm. 46, (1962), p. 274-277. 
CID PRIEGO, Carlos - "Las pinturas murales del Castillo de Alcañiz". Teruel. Separata. Teruel, núm. 20, (1958), p. 5-103.

DE GARMA Y DURÁN, Javier - Adarga catalana. Arte y heráldica y prácticas reglas del blasón, con ejemplos de las piezas esmaltes y ornatos de que se compone un escudo, interior y exteriormente. Barcelona: Orbis, 1954 [1753].

DE RIQUER, Martí y VALVERDE, José María - Historia de la literatura universal. Barcelona: Planeta, 1968.

DE SAGARRA Y SISCAR, Ferran - Sigil.lografia catalana. Inventari, descripció i estudi dels segells de Catalunya. Barcelona: Estampa d'Henrich, 1916-1932.

DE SAGARRA Y SISCAR, Ferran - "Los segells del rey en Jaume I". Boletín de la Real Academia de Buenas Letras de Barcelona. Separata. Barcelona, núm. 29, (1908).

DE ZURITA, Jerónimo - Anales de Aragón. Zaragoza: Institución Fernando el Católico, [1572], 1980.

DEL ARCO Y GARAY, Ricardo - Sepulcros de la Casa Real de Aragón. Madrid: Instituto Jerónimo Zurita, Consejo Superior de Investigaciones Científicas, 1945.

DELAROCHE, Paul (Dir.) - Trésor de Numismatique et de glyptique ou Recueil général de médailles, monnaies, pierres gravées, bas-reliefs, etc. tant anciens que modernes. Les plus intéressants sous le rapport de l'art et de l'histoire. Sceaux des rois et reines d'Angleterre. Paris: Didier et $\mathrm{C}^{\mathrm{ie}}$ Libraires-Éditeurs, 1858.

DESCLOT, Bernat - "crònica" in SOLDEVILA, Ferran - Les quatre grans cròniques. Barcelona: Selecta, [1972], $1983^{3}$.

DOMÍNGUEZ BORDONA, Jesús - El arte de la miniatura española. Madrid: Plutarco, 1932.

DOMÍNGUEZ BORDONA, Jesús - Miniatura. Madrid: Plus Ultra ediciones, 1958.

DURÀN I SANPERE, Agustí - Barcelona i la seva història. Barcelona: Curial. Documents de cultura, 1975.

ENGEL, Arthur y SERRURE, Raymond - Traité de Numismatique du Moyen Age. Paris: Arnaldo Forni Editore, 1890. 
ESPAÑOL BERTRÁN, Francesca - "Las pinturas murales del castillo de Alcañiz". Alqannišs. Boletín del Taller de Arqueología de Alcañiz. Extra de divulgación. El cerro de Pui Pinós y el castillo de Alcañiz. Una presencia histórica. Alcañíz, (1993), p. 30-32.

FERNÁNDEZ GONZÁLEZ, Etelvina - "El retrato regio en los Tumbos de los tesoros catedralicios" in BANGO (Dir.), 2000, p. 41-54.

FINESTRES Y DE MONSALVO, Jaime - Historia del Real Monasterio de Poblet, ilustrada con disertaciones curiosas sobre la antigüedad de su fundación, catálogo de abades y memorias cronológicas de sus gobiernos, con las de papas, reyes y abades generales del Císter tocantes a Poblet dividida en cinco libros (1753). Barcelona: Orbis, 1948.

FURIÓ, Antoni - El rey Conquistador. Jaime I: entre la historia y la leyenda. Valencia: Bromera, 2007.

GARDIN, Alessandra - "Presenza di immagini religiose in codici laici" in CECCANTI, Melania y CASTELLI, Maria Cristina (Dirs.) - Atti del III Congresso di Storia della miniatura. Il codice miniato. Rapporti tra codice, testo e figurazione. Firenze: Leo S. Olschiki, 1992, p. 375-385.

GIMENO BLAY, Francisco y SERRA DESFILIS, Amadeo - "Representar la dinastía: el manuscrito genealógico del monasterio de Poblet" in Genealogia dels Comtes de Barcelona i Reis d'Aragó. València: Patrimonio Ediciones, 1997.

GONZÁLEZ ANTÓN, Luis - "Los fueros, las cortes y el justicia de Aragón” in Aragón. Reino y Corona. Centro Cultural de la Villa de Madrid. Del 4 de abril al 21 de mayo de 2000. Zaragoza: Gobierno de Aragón, 2000.

GRABAR, André - La iconoclastia bizantina. Dossier arqueológico. Madrid: Akal, colección Arte y Estética, 1998 [1984].

GRABAR, André - Las vías de la creación en la iconografía cristiana. Madrid: Alianza, [1979], 1994.

GRIERSON, Philip - Monnaies du Moyen Age. Paris: Bibliothèque des Arts, 1976.

GUDIOL RICART, José - Pintura gótica. Madrid: Plus Ultra, 1955, vol. IX.

JAUME I - "Libre dels feyts del rei en Jacme” in SOLDEVILA, 1972. 
KAUFFMANN, C. M. - Catalogue of Foreign Paintings. Before 1800. London: Victoria and Albert Museum, 1973.

La ciudad de la memoria. Los códices de la catedral de Valencia. La ciutat de la memòria. Els còdexs de la catedral de València, Consorci de museus de la comunitat valenciana, Valencia, 1997.

LACARRA DUCAY, Ma Carmen - Las pinturas murales góticas del castillo de Alcañiz. Restauración. Zaragoza: Ministerio de Cultura, Diputación General de Aragón, Caja Inmaculada, 2005.

LACARRA DUCAY, M ${ }^{\mathrm{a}}$ Carmen - "Las miniaturas del Vidal Mayor: estudio históricoartístico" in Vidal Mayor. Estudios. Huesca: Excelentísima Diputación Provincial, Instituto de Estudios Aragoneses, 1989, p. 115-166.

LAIRÓN PLÀ Aureliano J. y VERCHER LLETÍ, Salvador - Guia de l'Arxiu Municipal d'Alzira. Alzira: Ajuntament d'Alzira, 1998.

Libre dels feyts del rey en Jacme. Edición facsímil del manuscrito de Poblet (1343) conservado en la Biblioteca universitaria de Barcelona. Barcelona: Universidad de Barcelona, 1972.

LLOMPART I MORAGUES, Gabriel y ESCANDELL I PROUST, Isabel - El llibre de franqueses i privilegis del regne de Mallorca. Estudi historicoartístic (en prensa).

MARÉS DEULÒVOL, Federico - Las tumbas reales de los monarcas de Cataluña y Aragón del monasterio de Santa María de Poblet. Barcelona: Asociación de Bibliófilos de Barcelona, 1952.

MAROT I SALSAS, Teresa - "La moneda medieval, moderna i contemporània. Els bitllets” in BARRAL (Dir.), Ars Cataloniae, Art de Catalunya, vol. 12, 1997.

MARTÍNEZ DE AGUIRRE ALDAZ, Javier Miguel - "En torno a la iconografía de la familia en el occidente medieval" in DE LA IGLESIA DUARTE, José Ignacio (Coord.) - La familia en la Edad Media. Nájera: Instituto de Estudios Riojanos, 2000, p. 413-453. MASSÓ TORRENTS, Jaume -“Inventari dels bens mobles del Rey Martí d'Aragó". Revue Hispanique. Recueil consacré a l'étude des langues, des littératures et de l'histoire des pays castellans, catalans et portugais. Paris, vol. XII, (1905). 
MATEU I LLOPIS, Felip - La moneda de los reinos de Valencia y Mallorca. Valencia: Anubar, 1977.

MATEU I LLOPIS, Felip - Les relacions del Principat de Catalunya i els Regnes de València i Mallorca amb Anglaterra i el paral.lelisme monetari d'aquests països durant els segles XIII, XIV i XV. Castelló de la Plana: Societat Castellonenca de Cultura, 1934. MELERO MONEO, Marisa - "La Virgen y el rey” in BANGO (Dir.), 2000, p. 419431.

MOLINA I FIGUERAS, Joan - "La ilustración de leyendas autóctonas: el santo y el territorio”. Analecta Sacra Tarraconensia. Revista de Ciencias Históricoeclesiásticas, Barcelona, núm. 70, (1997), p. 5-24.

NARBONA VIZCAÍNO, Rafael - "Héroes, tumbas y santos. La conquista en las devociones de Valencia Medieval". Saitabí. Revista de la Facultad de Geografía e Historia de la Universidad de Valencia Valencia, núm. 46, (1996), p. 293-319.

PALACIOS MARTÍN, Bonifacio - La coronación de los reyes de Aragón. 1204-1410. Aportación al estudio de las estructuras políticas medievales. Valencia: Anubar, 1975. PALACIOS MARTÍN, Bonifacio - "Imágenes y símbolos del poder real en la Corona de Aragón" in ). XV Congreso de Historia de la Corona de Aragón. El poder real en la Corona de Aragón (siglos XIV-XVI). Zaragoza: Gobierno de Aragón. Departamento de Educación y Cultura, 1996, vol. 1, p. 191-229.

PALACIOS MARTÍN, Bonifacio - "Los símbolos de la soberanía en la Edad Media. E1 simbolismo de la espada" in VII Centenario del Infante Don Fernando de la Cerda. Jornadas de Estudio. Ciudad Real: Instituto de Estudios Manchegos, 1976, p. 273-296.

PLANAS BÁDENAS, Josefina - El esplendor del gótico catalán. La miniatura a comienzos del siglo XV. Lleida: Estudi General, Edicions de la Universitat de Lleida, 1998.

PRADA, Fray Vicente - Sepulcros de la casa $\mathrm{R}^{\mathrm{L}}$. de Aragon, Condes de Urgel, Duques de Segorbe, y Cardona, Varones, Señores de Vassallos, Cavalleros, Obispos, Abades, y otros muchos, que descansan, y eligieron sepultura en el Insigne y R. Monasterio de Nrā $S^{\mathrm{ra}}$. De Poblet, Orden del Cister. Elvcidados por un indigno Monge de dicho $\mathrm{R}^{\mathrm{L}}$. 
Monast $^{\circ}$. Dedicados A la Concepcion Purissima de la Reyna y Emperatriz de los Cielos María S ${ }^{\text {ra }}$. Nrā. Año 1692, Biblioteca de Poblet, Ms. Arm. VI. C. 19.39.

PUIG I CADAFALCH, Josep y MIRET I SANS, Joaquim - "El Palau de la Diputació General de Catalunya". Anuari de l'Institut d'Estudis Catalans. Barcelona, vol. III, (1909-1910), p. 385-480.

RAYNAUD, Christiane - "La réprésentation du pouvoir dans le langage iconographique de l'enluminure française au debut du XVème siècle" Razo. Cahiers du Centre d'Études Médiévales de Nice. Nice, núm. 9, (1989), p. 149-167.

RUBIÓ I LLUCH, Antoni - Documents per a la història de la cultura catalana migeval (edició facsímil de l'any 2000). Barcelona: Institut d'Estudis Catalans, 1908.

SERRA DESFILIS, Amadeo - "Ab recont de grans gestes. Sobre les imatges de la història i de la llegenda en la pintura gòtica de la Corona d'Aragó". Afers. Fulls de Recerca i Pensament. Calarroja, núm. 41, vol. XVII, (2002), p. 15-35.

SERRA DESFILIS, Amadeo - "La historia de la dinastía en imágenes: Martín el Humano y el rollo genealógico de la Corona de Aragón”. Locus Amoenus. Bellaterra, núm. 6, (2002-2003), p. 57-74.

SERRANO COLL, Marta - Jaime I el Conquistador. Imágenes medievales de un reinado. Zaragoza: Institución Fernando el Católico, 2008.

SERRANO COLL, Marta - "El códice AGN B2 y la iconografía de coronaciones y exequias regias en la miniatura bajomedieval" in Ceremonial de Unción, Coronación y Exequias de los reyes de Inglaterra (AGN. Códices y Cartularios. B.2), vol. II. Estudios, Pamplona, Gobierno de Navarra e Institución Príncipe de Viana, 2008, p. 145175

SERRANO COLL, Marta - "La imagen como instrumento: el rey al servicio del códice, el códice al servicio del rey" in Libros con arte, arte con libros. Cáceres: Junta de Extremadura y Universidad de Extremadura, 2007, p. 659-667.

SINUÉS RUÍZ, Prbo., Atanasio - “Advocaciones de la Virgen en un códice del siglo XII". Analecta Sacra Tarraconensia. Revista de Ciencias Histórico-eclesiásticas. Barcelona, núm. XXI, (1948). 
URGELL, Ricard - "Munificencia regia. Llibre de franqueses i privilegis del regne de Mallorca" in BANGO (Dir.), 2000, p. 128-129.

YARZA LUACES, Joaquín - "La pintura española medieval. El mundo gótico" in PÉREZ SÁNCHEZ, Alfonso E. (Dir.) - La pintura española, Milán: Electa, 1995.

YARZA LUACES, Joaquín (Ed.) - La miniatura medieval en la Península Ibérica, Murcia: Nausícaä, 2007.

\section{COMO CITAR ESTE ARTIGO}

\section{Referência electrónica:}

SERRANO COLL, Marta - "Programas Ideológicos a través de la Imagem: algunos ejemplos de la Edad Media”. Medievalista [Em linha]. Nº9, (Dezembro de 2010). [Consultado dd.mm.aaaa]. Disponível em http://www2.fcsh.unl.pt/iem/medievalista/MEDIEVALISTA9lcoll9003.html. ISSN 1646-740X.

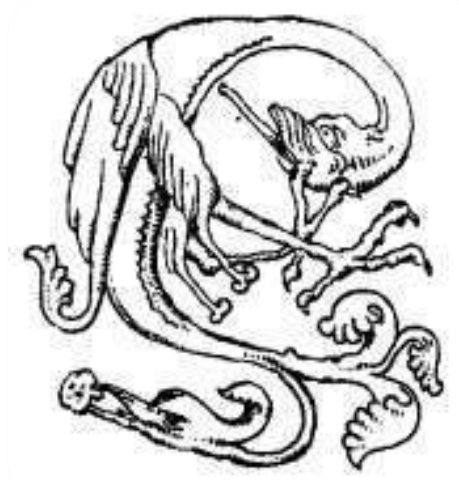

